\title{
Occult Features of Anarchism
}

\author{
Erica Lagalisse \\ London School of Economics
}

By exploring the hidden correspondences between classical anarchism, Renaissance magic and occult philosophy, this chapter advances the critical study of Left-political attachment to the 'secular', wherein Western anarchist and socialist cosmologies have been mystified. By historicizing Western anarchism and 'the revolution', it highlights the development of Left theory and praxis within clandestine masculine 'public' spheres of the radical Enlightenment, and how this genesis proceeds to inflect anarchist understandings of the 'political'. Inspired by ethnographic research among contemporary anarchist social movements in the Americas, this essay questions anarchist 'atheism' insofar as it has posed practical challenges for current anarchist-indigenous coalition politics. Moreover, in its treatment of 'secret societies' this essay has pedagogical utility for today's political activists as well as scholars of anarchism. Where popular fear of 'secret societies' is widespread, charting the construction of the secret society in European history has practical political importance. By attending to this history, we also witness the co-evolution of modern masculinity and secularized social movements as a textured historical process, and observe the privatization of both gender and religion in the praxes of radical counter-culture, which develops in complex dialectic with the "privitization" of gender and religion by the modern nation-state.

Let us explore the hidden correspondences between classical anarchism, Renaissance magic and occult philosophy, and other hidden features of anarchism besides. Let us historicize Western anarchism, whose genesis within clandestine masculine 'public'

How to cite this book chapter:

Lagalisse, E. 2018. Occult Features of Anarchism. In: Christoyannopoulos, A. and Adams, M. S. (eds.) Essays in Anarchism and Religion: Volume II. Pp. 278-332. Stockholm: Stockholm University Press. DOI: https://doi. org/Io.I6993/bas.i. License: CC-BY. 
spheres of the radical Enlightenment continues to inflect anarchist understandings of the 'political' even today. As I have related in my previous work concerning the exclusion of indigenous women and their concerns from anarchist public spheres, anarchist "atheism" can pose practical problems for current anarchist-indigenous coalition politics: our concern is beyond academic. ${ }^{\mathrm{I}}$ By illustrating the cosmology of classical anarchism I hope to complicate present-day anarchist attachments to "secular" analyses, in which anarchist theology is simply displaced and mystified. By attending to the same story, we witness the co-evolution of modern masculinity and secularized social movements as a textured historical process. We observe the privatization of both gender and religion in the praxes of radical counter-culture, which develop in complex dialectic with the "privatisation" of gender and religion by the modern nation-state (as above, so below).

Given its topic, this essay also necessarily engages with the history of "secret societies", wherein I have crafted my treatment to have pedagogical utility for today's political activists, as well as scholars of anarchism. Popular discussion of "secret societies" is currently widespread in the English-speaking world (and beyond), such that charting the construction of the secret society - both real and imagined - in European history arguably has practical political import, beyond being required for the particular academic task at hand.

It is therefore explicit that I come to the historical work at hand methodologically as an anthropologist, and for the purposes of practical intervention within social movements and politics today. It is from being a participant (2000-2005), and later ethnographer (2005-20I5), within contemporary anarchist social movements myself that I consider it important to unpack the history of "anarchism". While charting instances of "anarchy" throughout

I The previous work I refer to is: Lagalisse, Erica “"Marginalizing Magdalena”: Intersections of Gender and the Secular in Anarchoindigenist Solidarity Activism'. Signs - Journal of Women in Culture and Society. Vol 36, No. 3 . (20II). For a lengthier rehearsal of the present essay and discussion of its relation to my previous work the reader may look to Lagalisse, Erica (2018) Occult Features of Anarchism - With Attention to the Conspiracy of Kings and Conspiracy of the Peoples (Oakland: PM Press). 
time and space is a valid political project, there is also much to be gained by charting the emergence of "anarchism" as a distinct "ism" - and to do so does not necessarily detract from the aforementioned project, but rather keeps us honest as we proceed. ${ }^{2}$

I thus purposefully engage the past from the perspective of the present, tacking back and forth between diverse times and places to unearth bits and pieces of buried anarchist history based on an ethnographic imagination, using both secondary and primary sources. The interdisciplinary activity necessarily involved in such a project means that diverse specialists will be inspired, hopefully, to add some qualification, and thus lend their own knowledge and methodological strengths to the problem. Strangely, or perhaps not so strangely, the particular metaphysics of modern anarchism and its relation to social and historical context has not so far received the attention it deserves. This is no doubt partially due to the bias of many anarchists against religion, and the bias of many scholars against anarchism, but is perhaps also because the topic requires delving into the relationship between anarchism, occult philosophy and "secret societies" - all charged topics, even independently.

\section{First Premises: The Theology of Politics}

Carl Schmitt's general point that modern politics embodies secularized theological concepts is of basic relevance here. Schmitt also remarks, while pursuing his particular question regarding sovereignty, that every political idea "takes a position on the 'nature'

2 With respect to the questions of definition discussed in the introduction to this volume, I thus place myself among those who treat "anarchism" as a historical object; considering both "anarchism" and "religion" as discourses and practices developed in a certain social and historical context is a necessary precondition for this essay. Beyond my own proceeding exposition, with respect to "anarchism" as historical see also Carl Levy, 'Social Histories of Anarchism', Journal for the Study of Radicalism, 4 (20Iо), pp. I-44 (p. 8-IO); with respect to "religion" as historical see also e.g. Gil Anidjar, 'Secularism', Critical Inquiry, 33 (2006), pp. 52-76: "it was in the context of the colonial encounter that Christendom granted other communities and traditions the name it had only ever given itself religion - and reincarnated itself as 'secular'.” 
of man", presupposing that "he is either 'by nature good' or 'by nature evil"", and that to "committed atheistic anarchists, man is decisively good". ${ }^{3}$ This essay will dovetail with Schmitt's summary remark in only some ways; for our purposes a more nuanced discussion of the transcendence vs. immanence of divinity in the history of ideas within Western philosophy is crucial. I am inclined to point to Marshall Sahlins' work on The Native Anthropology of Western Cosmology. ${ }_{4}$ Sahlins suggests that the theological preoccupations underlying European political theory and science can be traced back at least as far as St. Augustine, and the quarrel among Pagan, Platonic, and Gnostic positions with that of the emerging Church authorities regarding the transcendence versus immanence of divinity, i.e. whether nature and humanity, whether together or separately, are wholly, partially, or latently divine, or are merely borne from the divine.

Cast in Sahlins' light, the persistent dualist conundrum in Western politics and social theory appears as a spiralling repetition of this same theological concern: There is Lust, which is not of God; there is Matter, distinct from Spirit; there is Desire, as opposed to Reason. Those who suggest some coercive force stops (or must stop) us from pursuing our "animal" desires follow the logic of a transcendent divinity. Since we are by nature so evil and base, God - or something else "out there" conceptually derived from Him - must keep us in line. For St. Augustine it was the State of Rome, for Hobbes any Sovereign will do (his "self-interest" clearly evolving from Augustine's "desire"). The "individual" vs. "society" polarity evident in most social theory is only another manifestation of the same - here God becomes "society" (rather than "the State"). One could go further and point out, for example, that in Durkheim's work the transcendent force appears as the "social fact" - from a mass of pre-social individuals

3 Carl Schmitt, Political Theology - Four Chapters on the Concept of Sovereignty, (Cambridge and London: MIT Press, I985), here pp. 56.

4 Marshall Sahlins, 'The Sadness of Sweetness: The Native Anthropology of Western Cosmology', Current Anthropology, 37 (I996), 379-4I8. (This particular history of ideas was first presented to me in the form of David Graeber's lecture notes from Dr. Marshall Sahlins' theory seminar ca. I990.) 
and desires emerges "society" which then serves to restrain these desires. Furthermore, note that in methodological individualism desire creates and governs society, whereas in cultural determinism desire creates the society that then governs desire, but it is always the same terms in play. In short, the transcendent God of theological dualism can be found just beneath the surface of every argument for centralized authority, including most canonical social theory (which anarchists, we may note, tend to recognize as "authoritarian").

What if we approached modern "anti-authoritarianism" with the same lens? I propose that a particular theological thread likewise runs through it. The same cultural baggage in tow, developing in dialectic with its opposite, modern anti-authoritarianism grapples with the same theological dilemma, yet attempts to resolve it differently by re-arranging the terms and with recourse to various pagan traditions and syncretic Christian hereticism itself. In other words, whereas many have located "anarchist" elements in Christian millenarianism and non-Western traditions, I wish to draw attention to the latter as elements of "anarchism" itself. Modern anarchism has never been purely atheist except in name, and rather develops based on overlapping syncretic pagan cosmologies that behold the immanence of the divine. In fact, utopian socialism, anarchism and Marxism each rely (in ways both similar and different, which I will tease out below) on a specific syncretic cosmology that is incipient in the Middle Ages, changing and crystallizing in the Renaissance, and gradually given a scientific makeover throughout the Enlightenment up to the $20^{\text {th }}$ century. Just as the secularization of the modern state privatizes religion but continues to embody a particular theology in its structure and ideology, the social movements that resist this dominant power structure go through a similar process of secularization in parallel, wherein gender and religion are displaced from "politics".

\section{A Heretical Account of the Radical Enlightenment}

Standard histories of modern anarchism often locate its precursors in the heretic movements (e.g. Anabaptists, Ranters and Diggers) that articulated combined critiques of Church authorities, the 
enclosures of private property and forced labour during the feudal period and early capitalist order. ${ }^{5}$ These movements often called for communal ownership in Christian idiom, e.g. by elevating "grace" over "works", yet the form and content of these heretical social movements was different than the Christian millenarian movements that preceded them. ${ }^{6}$ Millenarian movements were spurred on by a charismatic individual or momentous event, whereas the heretical movements had defined organizational structures and programmes for change, leading at least one historian to call them the "first proletarian international". ${ }^{7}$ What happened to effect the shift? And what does it mean that anarchist historians easily recognize such movements as "anarchist" when they are located safely in the past - as "precursors" - yet as soon as modern anarchism proper is articulated, religious levelling movements are seen as backward, if not heretical to anarchism itself?

The shift from the spontaneous millenarian movement to the organized heretic one had much to do with their incorporation of non-Christian ideas and mystical doctrines that began circulating in Europe during the Crusades. Platonic philosophy, Pythagorean geometry, Islamic mathematics such as Algebra, Jewish mystical texts and Hermetic treatises were all "rediscovered" via Muslim Spain and translated into Latin during this time. It is well known

5 see e.g. Peter Marshall, Demanding the Impossible - a History of Anarchism (London: Fontana Press, I993); Atindranath Bose, A History of Anarchism (Calcutta: World Press, I967); George Woodcock, Anarchism - a History of Libertarian Ideas and Movements (Cleveland: The World Publishing Co. I962).

${ }^{6}$ See Bose I967; Christopher Hill, The World Turned Upside Down Radical Ideas During the English Revolution (Harmondsworth: Penguin, I975); Peter Linebaugh and Marcus Rediker, The Many-Headed Hydra: Sailors, Slaves, Commoners, and the Hidden History of the Revolutionary Atlantic (Boston: Beacon Press, 2000); Sylvia Federici, Caliban and the Witch - Women, the Body and Primitive Accumulation (New York: Autonomedia, 2004); Peter Burke, Popular Culture in Early Modern Europe. (Cambridge: Cambridge University Press, I978.) Norman Cohn, The Pursuit of the Millennium: Revolutionary Millenarians and Mystical Anarchists of the Middle Ages (Oxford: Oxford U. Press, I970).

7 Federici 2004, p. 33. See also Cohn I970; Henry Charles Lea, A History of the Inquisition of the Middle Ages, (London: Macmillan, I922); Malcolm Lambert, Medieval Heresy: Popular Movements from the Gregorian Reform to the Reformation, (Oxford: Basil Blackwell, I992). 
that the creative re-composition of this ensemble inaugurated the Renaissance and later the "Enlightenment" on the level of high culture, but how the composite led to new levelling projects from below has received less attention. The Hermetica in particular is probably the least recognized fount of the modern Left, and yet an important thread running through it. ${ }^{8}$ The Hermetic tradition beholds a unified universe of which man is a microcosm ("As above, so below"), and wherein cosmic time beholds a pulsation of emanation and return. The Hermetic cosmos is hierarchically arranged in symmetrical diachronic and synchronic bifurcations (dyads) and trifurcations (triads), but a web of hidden "correspondences" and forces - alternately "energy" or "light" - cut across and unify all levels; in duration everything remains internally related - "All is One!" Significantly, humanity participates in the regeneration of cosmic unity - our coming to consciousness of this divine role is a crucial step therein. God and creation thus become one and the same, with the inevitable slip that our creative power - including intellectual power - is divine. The initiate must first purge himself of false knowledge in order to be able to receive the true doctrine; at any given moment only some are ready. Hermes himself explains that he "keeps the meaning of his words concealed" from those who are not. ${ }^{9}$

${ }^{8}$ The Hermetica or Corpus Hermeticum is a collection of texts written in the Ist or 2nd centuries A.D., yet during the Renaissance they were held to be the work of Hermes Trismegistus ("Thrice Greatest Hermes") imparting the mystical insights of ancient Egypt. Egypt was held to be an 'original' and thus superior civilization, one that nourished the philosophy of the Greeks, for example, such that the discovery of these texts was especially prized. When a monk arrived in Florence from Macedonia in I 460 carrying some of the Hermetic texts, Cosimo de Medici ordered his translator to drop Plato's dialogues immediately and turn his attention to them. See Frances Yates, Giordano Bruno and the Hermetic Tradition (Chicago: University of Chicago Press, I964), pp. I2, passim. For the Corpus Hermetica itself see Brian Copenhaver, Hermetica: The Greek Corpus Hermeticum and the Latin Asclepius in a New English Translation with Notes and Introduction (Cambridge: Cambridge U. Press, I992).

9 See Copenhaver I992, p. 58. The quotation is from Corpus Hermeticum I 6 . 
The Hermetica has proved adaptable to a variety of projects. Its neat metaphysical geometry, which arrived alongside algebra and the Pythagorean theorem, helped form a composite that lent itself to a massive investment in mathematical forms and understanding. Mathematics became the hidden architecture of the cosmos, the most permanent and basic truth, and revelation of these secrets certainly did permit an ability to build and create in ways never before imagined - providing both cathedrals and calculus, for example. A variety of mystical doctrines proliferated from the interaction of this composite with pre-existing natural philosophy, alchemy being only the most famous. Hermetic logic can also be discerned in a variety of other eclectic doctrines that developed throughout this period, such as Joachimism, Eckhartean mysticism, Paracelcism, the mathematics of John Dee, the arts of Ramon Lull, Rosicrucianism, vitalism (followed by spiritualism, mesmerism and more) all of which behold secret cosmic "correspondences" and sacred geometry, and in turn inspired the "scientific revolution" of the Enlightenment. ${ }^{10}$ To offer just one example, calculus was but the caput mortuum of Newton's search for the Philosopher's Stone (if not the Stone itself), his theory of aether

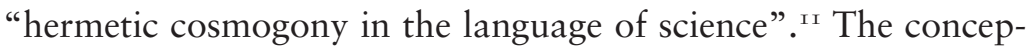
tual vocabulary of his physics (e.g. "attraction", "repulsion") was adopted from the Hermeticist Böhme via famous alchemist Henry More. ${ }^{\mathrm{I2}}$ The "disenchantment tale" of the Enlightenment is just

Io See the work of Frances Yates - The Art of Memory (London: Routledge, I966); The Rosicrucian Enlightenment, (London: Routledge, 2002 [1972]), as well as Giordano Bruno and the Hermetic Tradition, cited earlier; see also Richard S. Westfall, 'Newton and the Hermetic Tradition', in Science, Medicine and Society in the Renaissance, ed. Allen G. Debus (New York: Science History Publications, I972). To review primary sources see Brian Copenhaver's The Book of Magic - From Antiquity to Enlightenment (NY: Penguin, 20I 5), which includes substantial material from Renaissance figures (Pico, Ficino, Agrippa, Dee, Bruno, and more). See also lengthier discussion in Lagalisse (2018).

I Klaus Vondung, 'Millenarianism, Hermeticism, and the Search for a Universal Science', in Science, Pseudoscience, and Utopianism in Early Modern Thought, ed. Stephen McKnight (Columbia: University of Missouri Press, I992), p. I38.

12 See Ernst Benz, The Theology of Electricity. trans. Wolfgana Taraba (Allison Park: Pickwick Publications, I989). 

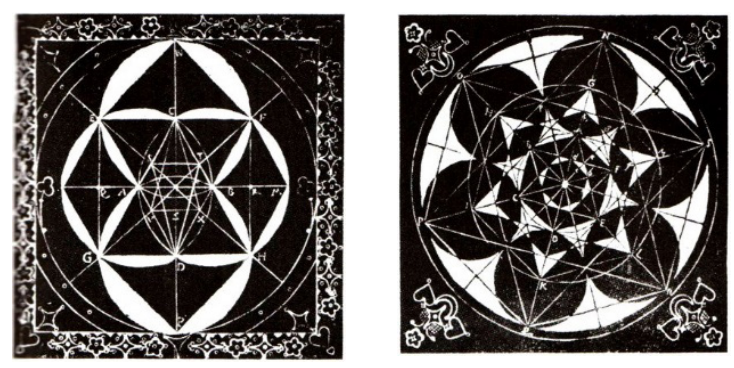

Fig 1. "Figura Mentis" and "Figura Intellectus" drawn by Giordano Bruno, Prague, I 588 . [Public domain], via Wikimedia Commons. https://commons. wikimedia.org/wiki/File:Bruno_Figura_mentis.jpg; https://commons. wikimedia.org/wiki/File:Bruno_Figura_intellectus.jpg.

that - a tale. The persecution of "magic" and "witches" among the poor during this period is rather best understood as a disciplinary measure directed specifically at the peasantry - and at women especially - insomuch as it served to enforce the logic of private property, wage work, and the transformation of women into producers of labour. As Sylvia Federici explains, fears around a declining population (work force) and the reproductive autonomy of lower-class women (practicing birth control) was what distinguished the witch from the Renaissance magician, who demonologists consistently passed over. ${ }^{13}$ Indeed the alleged devilish activities of the "baby-killing" witch were often plagiarized from the High Magical repertoire.

The Hermetica was also fundamental to the emergence of new social movements against systemic power, specifically Freemasonry and the revolutionary brotherhoods that proliferated during the $18^{\text {th }}$ and $19^{\text {th }}$ centuries. Unlike the millenarian and heretic movements before them, these social movements consisted of literate radicals more so than peasants, and were decisively masculine public spheres. Women's power within the peasant and heretic movements was ambiguous and never unchallenged, but women were actively involved, partially because renovated and

${ }^{13}$ Federici 2004. See also Ulinka Rublack's The Astronomer and the WitchJohane Kepler's Fight for his Mother (Oxford: Oxford University Press, 2015), where we behold one 'magical' man given the status of Imperial Mathematician while his 'magical' mother is imprisoned for witchcraft. 


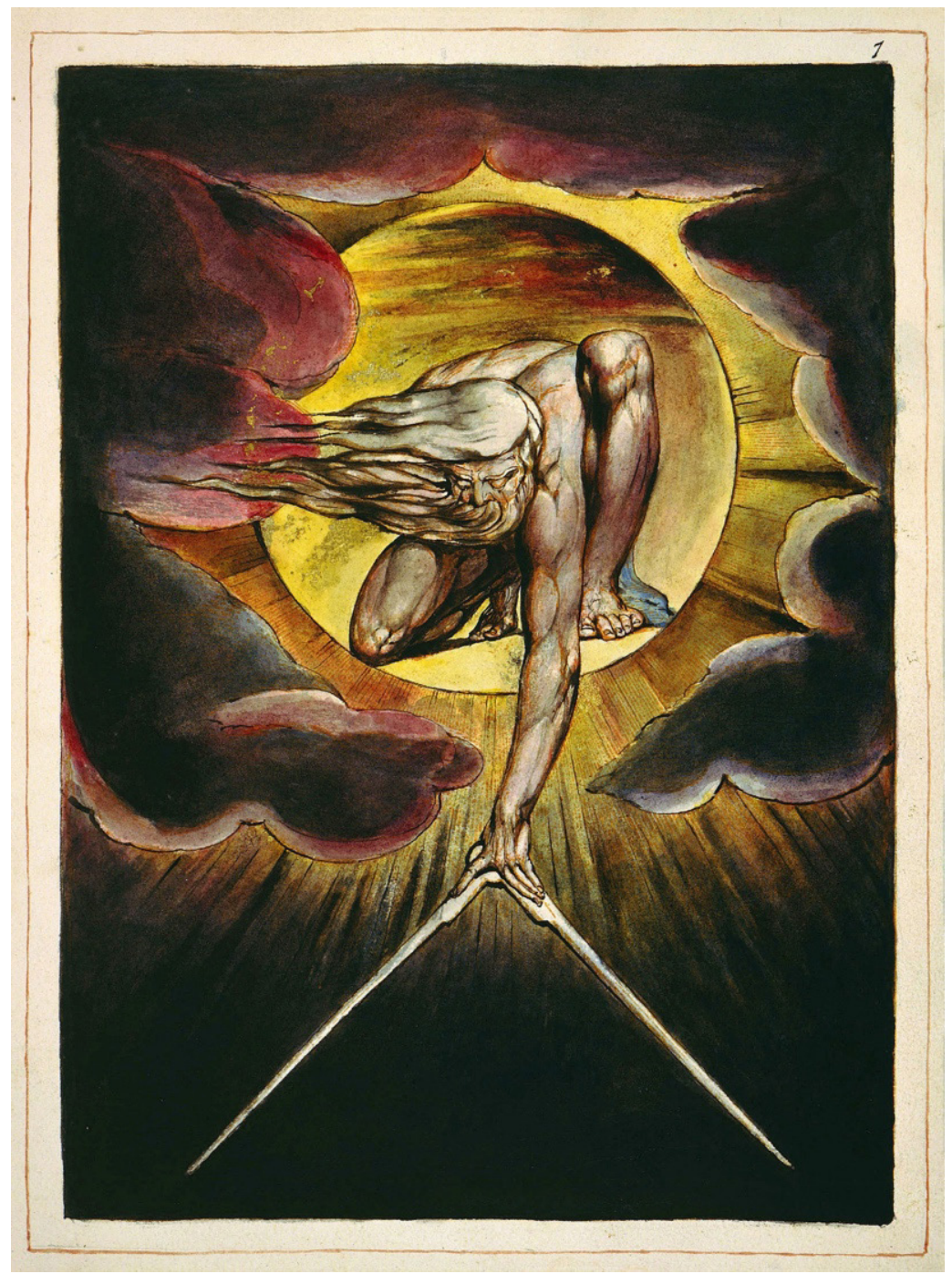

Fig 2. The compass is associated with power (in a geometrically gendered arrangement) by William Blake in Europe: A Prophecy (I794) —'When he sets a compass upon the face of the deep' (Proverbs 8: 27). [Public domain], via Wikimedia Commons https://commons.wikimedia.org/wiki/ File:Europe_a_Prophecy_copy_K_plate_or.jpg. 
syncretic Christian cosmologies granted them new footholds, and partially because women had the most to lose in the privatization of the commons. ${ }^{14}$ Freemasonry, on the other hand, is what social movements look like after the witch hunts: Just as Alchemists played at the creation of life while arresting feminine control over biological creation, speculative Masonry emerges in which elite males worship the "Grand Architect" upon the ashes of artisans" guilds while real builders were starving. By the establishment of the Grand Lodge in London in I 7 I7, the trade secrets of operative masons had become the spiritual secrets of speculative ones, lodge membership now thoroughly replaced by literate men lured by the ceremony, ritual, and a secret magical history supposedly dating back to the time of King Solomon and the Grand Architect of his temple, Hiram Abiff - Freemasonry itself has always involved a fantastic pastiche of Hermetic and Kabbalistic lore. ${ }^{\text {I5 }}$

${ }^{14}$ Op cit.

I5 Regarding Hermeticist currents in speculative Masonry see Jean Tourniac, 'Vie et perspectives de la franc-maçonnerie traditionelle' [ $2^{\text {nd }}$ edition], (Paris: Dervy-Livres, I978); Regarding the specific links Freemasons made between ancient Egypt and freemasonry, see for example the minutes of Le Conseil de l'Ordre du Grand Orient, April 25 I 887, reprinted in Christian Lauzeray, L'Égypte ancienne et la Franc-Maçonnerie (Paris: Éditeur Guy Trédaniel I988). J. P. Dubreuil in his Histoire des francmaçons, (Bruxelles: H.I.G. François, I 838) analyzes ritual form, dress, ceremonial objects, art and catechism to suggest allegories shared in the Egyptian, Jewish and Freemasonic traditions. See also Claude-Antoine Thory, Histoire de la fondation du Grand Orient de France (Paris, Chez P. Dufart, libraire, Quai Voltaire, N². I9, de l'imprimerie de Nouzou, rue de Clery, No. 9, I8I2). Further references in English regarding the social history of Freemasonry include Margaret Jacob, 'Freemasonry and the Utopian Impulse', in Millenarianism and Messianism in English Literature and Thought, ed. R.H. Popkin (NY: E.J. Brill, I988), as well as Margaret Jacob, The Radical Enlightenment - Pantheists, Freemasons and Republicans (London: George Allen and Unwin, I98 I), J. M. Roberts, The Mythology of the Secret Societies (London: Secker and Warburg, I972), and the (bibliography of) primary source materials offered within Dr. William Wynn Westcott's A Catalogue Raisonné of Works on the Occult Sciences, Vol III - Freemasonry, A Catalogue of Lodge Histories (England), with a Preface (London: F.L. Gardner, I9 12). Note that there are significant differences between the social development and organization of Freemasonry in England vs. on the European continent, yet as 
One Hermetic aspect of the Masonic cosmology that is key for our discussion, and discussed further below, is the notion that man and society tend toward perfection. The work of Spinoza ( $632-77$ ) was also, together and separately, an inspiration in this regard. In his 'Theological Political Treatise' ( 1670 ), Spinoza arguably provides the founding text of modern liberalism by effectively conflating the 'chosen people' and the chosen 'state' or 'society', and by relativizing the gift of prophecy as an imaginative (vs rational) capacity of men and women of all traditions ('gentiles'). ${ }^{16}$ The imports of Spinoza's complete oeuvre, across time and audience, are of course diverse (and contested), yet it is clear that with the Treatise he equipped contemporary European radicals with a dynamic philosophy that unified, divinised and animated the universe as well as honoured a deterministic vision of man and nature, thus providing a new religious vision and a renovated foundation for social resistance at once, which contemporaries named "pantheism". ${ }^{17}$ This word, apparently first used by John Toland (I670-I722), was taken up during the period in question to refer to a metaphysics that re-emphasized the vitalistic, spirit-in-matter qualities of nature, and tended to deify the material order in the process. ${ }^{18}$ This new faith in scientific progress encouraged the conception of temporal institutions both as permanent, and as vehicles for enacting fantasies

their consideration is not crucial to our present study these will be bracketed here.

I6 See Benedict de Spinoza, Theological Political Treatise, edited by Jonathan Israel, (Cambridge: Cambridge University Press, 2007 [I670]), especially Chapter 2, "On the Prophets", [I], [3]; Chapter 3, "On the Vocation of the Hebrews", [8], [9], passim.

17 Op cit. See also Benedictus de Spinoza, Ethics. (NY: Oxford University Press, 2000), Benedictus de Spinoza, The Cartesian principles and Thoughts on metaphysics. (Indianapolis: Bobbs-Merrill, I963). Regarding the role and charges given Spinoza's work within the culture of the 'radical Enlightenment' see Jonathan Israel, Radical Enlightenment (Oxford: Oxford University Press, 200I), Jonathan Israel, A Revolution of Mind Radical Enlightenment and the Intellectual Origins of Modern Democracy, (Princeton: Princeton University Press, 2010), as well as Jacob, The Radical Enlightenment, regarding contemporary articulations of "pantheism" in particular, and their relation to Spinoza's ideas.

${ }^{1} 8$ See e.g. Jacob, The Radical Enlightenment, p. xi; 32-3. 
of progress: A new heaven on earth would be manifest through the works of men themselves.

The Traité des Trois Imposteurs that Masons circulated clandestinely during the $\mathrm{I} 8^{\text {th }}$ century refers to Moses, Jesus and Mohammed as the three "Imposters" in question, yet the coterie who printed it included Toland, who in his Pantheisticon (I 720 ) elaborated a new ritual that claimed to combine the traditions of Druids and ancient Egyptians and included the following calland-response: "Keep off the prophane People/ The Coast is clear, the Doors are shut, all's safel All things in the world are one, And one in All in all things/ What's all in All Things is God, Eternal and Immense/ Let us sing a Hymn Upon the Nature of the Universe." Masons imagined themselves simultaneously the creators of a new egalitarian social order and protagonists of cosmic regeneration, all articulated in the language of sacred architecture. Their society was anti-clerical, yet espoused a pantheism that infused their social levelling project with sacred purpose. Theirs was a pyramidal initiatic society of rising degrees and reserved secrets, but one in which all men met "upon the level". ${ }^{19}$

The Masonic levelling project was not altogether radical. It is true that Masonic lodges were frequented by elite men who instrumentalised them to further consolidate their power, and that the Masonic project was one of limited reforms, one to which Jews, women, servants and manual labourers were denied entry. ${ }^{2 \circ}$

I9 See Jacob, 'Freemasonry and the Utopian Impulse', pp. I27-I30; regarding the Traité des Trois Imposteurs, see Jacob, The Radical Enlightenment, chapter 7; the quotation from the Pantheisticon is on pp. I22-I 23; see also xiii. See also J. M. Roberts, The Mythology of the Secret Societies (London: Secker and Warburg, I972), Chapter 2. Regarding Freemasons beholding a new heaven on earth, see also "SONG II" in The Universal Masonic Library, Vol. III - Preston's Illustrations of Masonry, (NY: W.Leonard \& Co., Aferican Masonic Agency, I 855 , pp. 364-5), a work which begins with a section titled "Reflections on the Symmetry and Proportion in the Works of Nature and on the Harmony and Affection among the various Species of Beings”: “. . .But, ungrateful unto Heaven/ The rebel was from Eden driven. [Verse 4] From thence proceeded all our woes/ Nor could mankind one comfort cheer/ Until Freemasonry arose/ And form'd another Eden here. ..”.

20 See e.g. Alberto Valín Fernández, 'De masones y revolucionarios: una reflexión en torno de este encuentro', Anuario Brigantino, 28 (2005), 
It is also true that the Masonic ideal of merit as the only fair distinction allowed room to critique the tension between formal ideals and actual practice, and that Masonic lodges were the first formal public association in $18^{\text {th }}$ century Britain to take up the cause of the "workers' question" - albeit on a purely philanthropic level - by founding hospices, schools and assistance centres for proletarian workers. ${ }^{21}$ In pre-revolutionary France, lodges first began accepting small artisans then proletarian workers as well, lowering fees and abolishing the literacy requirement for entrance to this end. By I 789 there were between 20,000 and 50,000 members in over 600 lodges, and it was no longer possible for participants to reasonably claim they were manifesting an egalitarian social order by merely gathering to discuss literature, science, and the cultivation of Masonic wisdom. ${ }^{22}$

I73-98, as well as his monograph length work, Alberto Valín Fernández, Masonería y revolución - del mito literario a la realidad historica (Santa Cruz de Tenerife: Ediciones Idea, 2008). In the words of one Bordeaux lodge master (I745), "le privilege de l Égalité deviendroit [sic] un abus bien dangereux, si sous ce prétexte on admettrait indifferément tous les états", cited in Roberts, p. 50, who is citing W. Doyle, 'The Parlementaires of Bordeaux at the End of the Eighteenth Century I775-I790', (Oxford: Oxford, PhD diss., I967) p. 338. According to another contemporary Freemason (I744), the sister lodges organized for women were but for "immoral purposes" and "beguiling" them "into thinking they had penetrated the secrets", in Roberts, pp. 50-5 I, who cites in turn La Francmaçonne ou révélation des mystères des franc-maçons (Brussels, I744), p. II-I 5 .

${ }^{21}$ See Jacob, 'Freemasonry and the Utopian Impulse', especially p. I42; Valín Férnandez, 2005, discusses Freemasonic philanthropy related to the "workers question" on p. I 82.

${ }^{22}$ Regarding the reforms in favour of proletarian workers, see Valín Férnandez, 2005, p. I83; Valín Férnandez is following the work of André Combes - see, e.g., André Combes, Les trois siècles de la francmaçonnerie française (Paris: Dervy, 2006). The figures given regarding lodge membership in 1789 are from Daniel Mornet, Les origines intellectuelles de la révolution française (Paris: Librairie Armand Colin, I933), and Daniel Ligou, 'La Franc-Maçonnerie Française Au XVIII Siècle (positions des problèmes et état des questions)', Information Historique (I964). One overview of this process in English is Margaret Jacob, Strangers Nowhere in the World - the Rise of Cosmopolitanism in Early Modern Europe (Philadelphia: University of Pennsylvania Press, 2006). 


\section{The Revolutionary Brotherhoods}

Here we arrive at the question of "conspiratorial" revolutionary brotherhoods that has been exploited in paranoid intrigue. ${ }^{23} \mathrm{On}$ one hand, due to the utopian rhetoric developed in the Masonic "public" sphere, some members became directly involved in revolutionary activities, both in France before the Revolution, as well as throughout Europe in the years immediately following. On the other hand, it is true that many revolutionaries who were not necessarily Masons made use of the lodges' existing infrastructure and social networks to further their cause. Yet others simply adopted Masonic iconography and organizational style, which had accrued a measure of symbolic power and legitimacy, in developing their own revolutionary associations. It is not possible in retrospect to distinguish entirely between these phenomena, the salient point being that the revolutionary brotherhoods that proliferated at the turn of the $19^{\text {th }}$ century derived much of their power from their association with perennial secrets and magical power, and that this imaginary and their related style of social organization were fundamental to the development of what we come to recognize as modern revolutionism. ${ }^{24}$

${ }_{23}$ There is a more written on the connection between Freemasonry and revolutionary movements in French, Spanish, Italian and German than in English. Valín Fernández offers a substantial bibliography of Spanish, French and Italian sources (pp. I73-98). Roberts offers further sources in French, Italian and German. In English one does well to follow Margaret Jacob, yet she does not concern herself with revolutionary movements on the continent.

${ }^{24}$ I proceed to summarize below, yet note that a detailed genealogy of the revolutionary brotherhoods in question (e.g. The Corresponding Society, the Conspiracy of Equals, the League of the Just, the Communist League, the Fraternal Democrats, etc.) can be found in Julius Braunthal, History of the International, Vol. I - I864-I9I4, (NY: Frederick A. Praeger, I967), Chapters 4-6. Valín Férnandez, 2005, also treats the question of descent, vs. imitation, vs. overlap. Note that Eric Hobsbawm's Primitive Rebels - Studies in Archaic Forms of Social Movement in the I9th and 2oth Centuries (NY: Norton, I959), although inflected with a critical Marxist bias, is also a further resource in English for an overview of revolutionary fraternities and their rituals. Roberts also discusses the "seedtime of the political secret societies" in Chapter 7 . 
Adam Weishaupt (I748-1830), a young Bavarian professor who founded the Illuminati in I776, was one of few convinced egalitarians of his day. His revolutionary agenda involved the complete dismantling of the State, Church and institution of private property, all justified by a revamped Christian millenarianism affected by readings of J.J. Rousseau and the Eleusinian mysteries, and organizationally inspired by the secret association of the Pythagoreans. ${ }^{25}$ According to Weishaupt, our true "fall from grace" was our submission to the rule of government:

"Let us take Liberty and Equality as the great aim of [Christ's] doctrines and Morality as the way to attain it, and everything in the New Testament will be comprehensible. . . Man is fallen from the condition of Liberty and Equality, the STATE OF PRE NATURE. He is under subordination and civil bondage, arising from the vices of man. This is the FALL, and ORIGINAL SIN. The KINGDOM OF GRACE is that restoration which may be brought about by Illumination." ${ }^{26}$

Yet "Do you really believe it would be useful", he asked, "as long as countless barriers still remain, to preach to men a purified religion, a superior philosophy, and the art of self-government?", "[s]hould not all these organizational vices and social ills be corrected gradually and quietly before we may hope to bring about this golden age, and wouldn't it be better, in the meanwhile, to propagate the truth by way of secret societies? Do we not find traces of the same secret doctrine

25 See René Le Forestier, Les Illuminés de Bavière et la franc-maçonnerie allemande (Genève: Slatkine Megariotis Reprints, (I974 [I9I4]) or Israel, A Revolution of Mind, (who both cite further sources in German), or Roberts who refers to Le Forestier. (Roberts is most concerned with the mythology that developed around "secret societies" rather than their objective history.)

${ }^{26}$ Weishaupt in communiqué titled "Spartacus to Cato" (Spartacus was Weishaupt's pseudonym), quoted by John Robison in Proofs of a Conspiracy against All the Religions and Governments of Europe, Carried on in the Secret Meetings of Freemasons, Illuminati, and Reading Societies (Dublin: W. Watson and Son, I798), pp. 92-3. To consult original German see "Spartacus to Cato" ( 5 March I778) in Richard van Dülman, Der Geheimbund der Illuminaten (Stuttgart: Verlag, I975), pp. 220. 
in the most ancient schools of wisdom?" ${ }^{27}$ For Weishaupt, only the "immanent revolution of the human spirit" (die bevorstehende Revolution des menschlichen Geistes), driven by a "widely propogated universal Enlightenment" (verbreitete allgemeine Aufklärung) will break the chains of tyranny, yet repressive political conditions required a discreet Enlightened revolutionary elite in the meantime. ${ }^{28}$

Weishaupt had joined a Masonic lodge in $\mathrm{I} 774$ but had left shortly after, not satisfied with the level of critique he found therein. A year after founding his more radical group however, the members together decided in I 777 to join lodges once more in order to find new recruits, and the strategy worked. The Illuminati grew from Weishaupt and five students in 1776 to fifty-four members in five Bavarian cities by I779, and eventually extended to Italy, Lyon and Strasbourg to include figures such as Goethe, Schiller, Mozart and Herder. The pyramid structure of the network, modelled on Masonic form, was organized into three grades (the Minervale, Minervale Illuminato, and inner circle of Areopagites) and became both an agency for the transmission of commonplace Enlightenment ideas and attitudes and a "quasi-religious sect" at once, in which men met to contemplate the utopian regeneration of society. ${ }^{29}$ Its growth was short-lived however. In I 783 , a Minervale Illuminato left the order discontented and shared its radical ideas with his employer, a duchess of the Bavarian royal family. Ensuing suspicions that the Illuminati were connected

${ }^{27}$ Le Forestier's French translation of the full passage from German is as follows, "Croyez-vous qu-il serait utile, tant que d'innombrables obstacles ne seront levés, de prêcher aux hommes une religion épurée, une philosophie supérieure et l'art de se gouverner soi-même?. . .ces vices d'organisation et ces tares sociales ne doivent-ils pas être corrigés peu à peu et sans bruit, avant qu'on puisse espérer amener cet âge d'or et ne vaut-il pas mieux, en attendant, propager la vérité par le moyen des sociétés secretes?. . . Trouvons-nous des traces d'une pareille doctrine secrete dans les écoles de sagesse les plus anciennes. . .? Ne remarquez-vous pas qu'une telle institution d'éducation progressive a existé depuis les temps les plus anciens?", in Le Forestier, pp. 283. The English translation above is mine.

${ }_{28}$ See Israel, pp. 78; Israel cites Adam Weishaupt, 'Anrede an die neu aufzunehmenden Illuminatos dirigentes' in van Dülman.

29 See Roberts, pp. I $8-124$; Israel, pp. 73-80. The direct quote is from Roberts, p. I 22. 
with an Austrian plot to annex the Electorate (and perhaps worse) alarmed the government, and a repressive campaign began. By the end of the $18^{\text {th }}$ century, stories vilifying the Illuminati and the Freemasons - who were all "under its control" - were in full force. Fearing the death penalty, members went into hiding or exile. ${ }^{3 \circ}$

The turn of the century saw a proliferation of other revolutionary societies across Europe that mimicked the forms of Freemasonry and the Illuminati, including the Charbonnerie and Carbonari, the Mazzinians and le Monde, all constituting an international network of revolutionary movements that had certain ideological, if not organizational, solidity. The politics of Babeuf (I760-I797), who was imprisoned in the aftermath of the French Revolution as the prime agent of the "The Conspiracy of Equals" (and anticipated Proudhon's argument that "Property is Theft" by forty-three years) as well as the politics of Phillipe Buonarotti (I76I-I837), who founded the Sublime Perfect Masters in I809, likewise bear a family resemblance. ${ }^{3 \mathrm{I}}$ It did make certain practical

30 As writes Jonathan Israel, "Contemporary observers like the ultrareactionary court official Ludwig Adolf Christian von Grolman (I749I 809) - who published a well-known collection of secret documents of German Illuminatism, die Neuesten Arbiter des Spartacus und Philo in I793 - protested that the highest grades of the order were, in effect, a clandestine vehicle for the propagation of materialist and atheistic ideas and that at the core of the highest mysteries of the organization's first grade, the so-called Philosophengrad (philosopher's grade), lay unadulterated Spinozismus (Spinozism). . .that everything that exists is matter, that God and the universe are the same, and that all organized religion is a political deception devised by ambitious men". See Israel, pp. 74, who cites in turn Martin Mulsow "Adam Weishaupt as Philosoph", in Die Weimarer Klassik und ihre Geheimbünde, edited by W Müller-Seidel and W. Reidel (Würzburg, 2003), 27-66; W. Reidel, "Aufklärung und Macht. Schiller, Abel und die Illuminaten" in Weimarer Klassik. For overview in English see also Roberts, pp. I 25-I 28.

${ }^{31}$ Regarding Babeuf see R.B. Rose, Gracchus Babeuf - the First Revolutionary Communist (Stanford: Stanford University Press, I978), or Albert Fried and Ronald Sanders, Socialist Thought - a Documentary History (NY: Anchor Books, I964). Regarding Buonarotti see Elizabeth L. Eisenstein, The First Professional Revolutionist: Filippo Michele Buonarotti (I76I-I 837) (Cambridge: Harvard University Press, I959). During his trial defense, Babeuf explained that " $[\mathrm{t}]$ he institution of private property is a surprise that was foisted upon the mass of simple and honest souls. The laws of this institution must necessarily bring about the 
sense to organize in a clandestine fashion, as proposed by both Babeuf and Buonarotti (beyond Weishaupt) at the turn of the century, as following the French Revolution the feudal dynasties of Russia, Austria, Prussia, Italy and Spain, with powerful allies in all other European countries and the Catholic church, had formed their own international organization, pledging themselves to forcible action within states in which absolute sovereigns felt threatened by, in the words of Tsar Nicholas, "revolutionary inroads". ${ }^{32}$ These conservative governmental powers formalized themselves as the "Holy Alliance" at the Congress of Vienna in I8I4, and proceeded to cooperate in international publication bans, surveillance and repression of militants. This posed serious practical problems. To suggest the prevailing political mood, consider the Fraternal Democrats' reply to the Brussels Democrats (then led by Karl Marx) in I 846: "[Marx] will tell you with what enthusiasm we welcomed his appearance and the reading of your address ... We recommend the formation of a democratic congress of all nations, and we are happy to hear that you have publicly made the same proposal. The conspiracy of kings must be answered with the conspiracy of the peoples...”. ${ }^{3}$

existence of the fortunate and unfortunate of masters and slaves. The law of heredity is supremely abusive. . it follows that this possession by a few is usurpation. . .whatever an individual hoards of the land and its fruits beyond what he needs for his own nourishment has been stolen from society", in Fried and Sanders, pp. 63-4). Buonarotti had a low opinion of established freemasonry, but nevertheless admitted only Masons into the brotherhood for the express purpose of using established lodges as a nursery for revolutionary ideas in a Christian language. Every candidate for supreme command of the Sublime Perfect Masters had to infiltrate a masonic lodge and rise through its hierarchy to a key position, successfully altering the structure of lodges in Tuscany, Piedmont and Lombardy by adding a third grade that dovetailed the lodges' hierarchy with their own. See Eisenstein, The First Professional Revolutionist, p. 45, passim). Louis August Blanqui (I805-I88I) shifted from espousing republicanism to radical democracy under Buonarotti's influence, and later created his very own sect - the Society of the Seasons. For further discussion of Blanqui and his influence on revolutionary practice and the work of Karl Marx in particular see Braunthal, Chapter 6, especially pp. 46-52.

32 Cited in Braunthal, pp. 39.

33 Cited in Franz Mehring, Karl Marx: The Story of His Life, (London: Fitzgerald, I936), pp. I42-3. Regarding the Holy Alliance see Braunthal, 
In other words, the pyramidal structure of all the revolutionary organizations, in which each level of the pyramid would know only its immediate superiors, clearly had a practical function insomuch as it protected revolutionaries from repression in this era of increasingly consolidated state power and surveillance. The resemblances were not necessarily due to ex-Illuminati members starting up new groups, but rather partially due to the fearful accounts thereof propagated by governments at the time, which had the ironic effect of inspiring others to try the strategy. ${ }^{34}$ The specific organization and ritualization of all this revolutionary activity clearly had other functions as well: the Brotherhoods affirmed and unified the aspirations of illuminated men whose purpose it was to steer mankind toward achieving perfection on (this) earth. Bakunin, $32^{\text {nd }}$ degree Mason himself, appeared to feel the same calling when he founded his own secret "International Brotherhood" in Florence in I 864 that mirrored Weishaupt's vision almost exactly one hundred years later. ${ }^{35}$ The main difference between the two was that Bakunin's Brotherhood was meant to infiltrate the First International and wrest it from the authoritarian socialists' control, as opposed to infiltrate Masonic lodges in order to wrest them from Liberals' control. This is far from the only way in which Masonry and the International Workingman's Association (IWA) coincide.

Chapter 5 - “The Counterrevolutionary International”, especially pp. $37-43$.

34 As Julius Braunthal writes, for example, it was in fact Buonarotti's book Babeuf and the Conspiracy for Equality, which "conveyed to posterity the ideas and methods of the Babeuvists. It appeared in Brussels in I 828 and two years later in Paris. In I 838 the Chartist leader, Bronterre O'Brian, published an English translation. Marx read the book in I 844 and, together with Engels, considered arranging for a German edition, to be translated by Moses Hess.”, pp. 35-6. See also Arthur Lehning, From Buonarroti to Bakunin - Studies in International Socialism (Brill: Leiden, I970).

35 Bakunin became a member of the order during the 1840 s in Paris; see Nunzio Pernicone. Italian Anarchism, I864-I892. (New Jersey: Princeton University Press. I993 pp I6, passim) for discussion of both Bakunin's masonry and activities in Florence. 


\section{Illuminism in the IWA}

By the mid-I $9^{\text {th }}$ century many members of Masonic society had come to feel the proletarian struggle coincided with their greater cause, and the use of Masonic organizations as a cover for revolutionary activity was now a long tradition, as was the tendency to use Masonic rites, customs, and icons to emblematically symbolize the values of equality, solidarity, fraternity, and work. ${ }^{36}$ Pierre-Joseph Proudhon, a Mason who lived to see the formation of the IWA, wrote that "The Masonic God is neither Substance, Cause, Soul, Monad, Creator, Father, Logos, Love, Paraclete, Redeemer...God is the personification of universal equilibrium". ${ }^{37}$ In Proudhon's day, the British lodges were admitting increasing numbers of proletarian members - particularly skilled and literate workers - and had come to support the workers' struggle to the extent that the first preparatory meeting of the IWA on August 5, I 862, attended by Karl Marx among others, was held in the Free Masons Tavern..$^{8}$ Many of those in attendance were "socialist Freemasons", a phrase applied at the time to the members of the small lodges founded in 1850 and 1858 in London by exiled French republicans, and which involved many members of diverse national backgrounds - the "Memphite" lodges, named

${ }^{6}$ See Valín Fernandez, 2005, pp. I 8I.

37 This is Proudhon writing in Of Justice in the Revolution and the Church (I 858 ), cited in Heleno Saña, El Anarquismo, De Proudhon a CohnBendit (Madrid: Indice, I970), p. 40. It is arguably telling of bias in anarchist historiography that many English language reprints of Proudhon do not include such material; as just one example, L.S. Edwards and Elizabeth Fraser, Selected Writings of Pierre-Joseph Proudhon (London: Macmillan and Co. Ltd., I969) includes excerpts from Of Justice and the Revolution in the Church and cut out this part, preferring Proudhon in the following mode: "God is stupidity and cowardice; god is hypocrisy and falsehood; god is tyranny and poverty" (I 846). For further discussion and references regarding the religiosity of figures such as Proudhon and Kropotkin, see Harold Barclay, "Anarchist Confrontations with Religion" in New Perspectives on Anarchism (Lanham: Lexington, 2010), (note the relationship is one of "confrontation"), as well as the synthetic overview and multiple further sources offered in Alexandre Christoyannopoulos and Lara Apps, "Anarchism and Religion" in The Palgrave Handbook of Anarchism (Basingstoke: Palgrave Macmillan, 2019).

${ }^{8}$ See e.g. Valín Férnandez, 2005 , pp. I82. 
after the sacred Egyptian burial ground. The immediate objectives of the Memphite programme were twofold: The struggle against ignorance through education, and helping the proletarians in their struggle for emancipation by way of Proudhonian mutual aid associations. Louis Blanc was among the members of the Memphite lodges (the Loge des Philadelphes in particular) along with at least seven other official founders of the IWA. In Geneva also, the local wing of the IWA was often called the Temple Unique and met in the Masonic lodge of the same name. ${ }^{39}$ Many present at the time observed that the incipient IWA's organizing power was so weak that if it were not for the organizing efforts of socialist Freemasons, the official founding meeting of the IWA on September $28^{\text {th }}$ I 864 would never have come to pass. ${ }^{40}$

Communist and anarchist symbolism, such as the red star and the circle-A, date back to this period and also have Masonic origin. The star, which hosts an endless charge of esoteric meanings in both the Hermetic and Pythagorean traditions, had been adopted in the $I 8^{\text {th }}$ century (some say $I 7^{\text {th }}$ ) by Freemasons to symbolize the Second Degree of membership in their association - that of Comrade (Compañero and Camarade in my sources). Among socialists, it was first used by members of the Memphite lodges and then the IWA. Regarding the Circle-A, early versions like the $19^{\text {th }}$ century logo of the Spanish locale of the IWA are clearly composed of the compass, level and plumbline of Masonic iconography, the only innovation being that the compass and level are arranged to form the letter $\mathrm{A}$ inside of a circle. ${ }^{4 \mathrm{I}}$

39 Op cit. pp. I79, I 82-4.

40 See Valín Férnandez, 2005, p. I82-3. See also his main source in this regard, Max Nettlau, La anarquía a través de los tiempos (Barcelona: Editorial Antalbe, I979 [I929]), who references accounts written by those present at the time.

4I See Valín Férnandez, 2005, pp. I80-88. Valín Férnandez' original intuition was that he might find the Level as symbol of egalitarianism dating back to the Levellers of the English Revolution, but neither the Levellers, Diggers or any other pre-Masonic movement used these tools to symbolize their struggle and values; they are clearly taken from the Masonic repertoire. The logo of the Spanish locale of the IWA presented in Fig. I is reprinted in Valín Férnandez, 2005 , pp. I 83. 


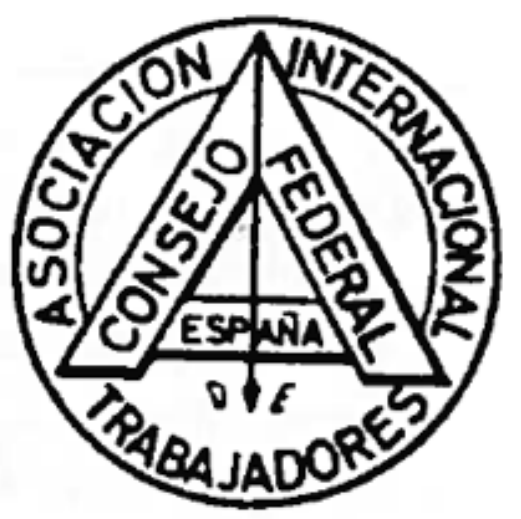

Fig 3. The seal of the Consejo Federal de España de la A.I.T. circa I 870. By Vilallonga (Own work, based on AIT.jpg.) [CC BY-SA 2.5 (https:// creativecommons.org/licenses/by-sa/2.5)], via Wikimedia Commons. https:// commons.wikimedia.org/wiki/File:FRE-AIT.svg.

Over time these symbols have developed a new complement of meanings - many $2 I^{\text {st }}$ century anarchists don't even know that the star used by communists, anarchists and Zapatistas alike is the pagan pentagram, and are not reminded of the mathematical perfection of cosmogony when they behold it, just as they do not necessarily realize there is a genealogical link between the (neo)pagan Mayday celebration and today's anarchist Mayday marches..$^{42}$ In the $19^{\text {th }}$ century, however, these symbolic associations were well known by those involved, and their adoption reflected how much they resonated with mystical and historical weight. Even Bakunin, while he rejected the personal God of his Russian orthodox childhood, put forward a pantheistic revolutionism. In a letter to his sister (I 836) he wrote, "Let religion become the basis and reality of your life and your actions, but let it be the pure and singleminded religion of divine reason and divine love. . . [I]f religion

${ }^{42}$ These of course commemorate the Haymarket massacre (I 886), but it is no coincidence that there was much upheaval in Chicago that day, because revolutionaries had been honouring Mayday since before the time of the Illuminati, which was also founded on this symbolic day. 
and an inner life appear in us, then we become conscious of our strength, for we feel that God is within us, that same God who creates a new world, a world of absolute freedom and absolute love. . . that is our aim". ${ }^{43}$

Throughout the $19^{\text {th }}$ century the only people involved in the revolutionary scene who were consistently annoyed by this sort of mysticism were Marx and Engels. Proudhon's ramblings about God as Universal Equilibrium were the sort of thing Marx and Engels objected to and contrasted with their own brand of "scientific socialism" - "the French reject philosophy and perpetuate religion by dragging it over with themselves into the projected new state of society". ${ }^{44}$ Bakunin and Marx differed on this point and a number of others, the most famous being the role of the State. Whereas Marx considered a state dictatorship of the proletariat to be a necessary moment in his historical dialectic, Bakunin espoused the notion of a secret revolutionary organization that would "help the people towards self-determination, without the least interference from any sort of domination, even if it be temporary or transitional". ${ }^{45}$ Bakunin also wrote that he saw our

43 Cited in in Arthur Lehning, Mikhail Bakunin - Selected Writings (Cape: University of Michigan Press, I973), pp. 34-5. Bakunin is much better known among anarchists living today for his reversal of Voltaire's famous aphorism - "if God really existed, it would be necessary to abolish him"; see Mikhail Bakunin, God and the State, ed. Paul Avrich (NY: Dover Publications Inc., I970).

44 See Friedrich Engels, 'Progress of Social Reform on the Continent', in Karl Marx and Friedrich Engels - Collected Works, Vol. 3, ed. Robert Tucker (NY: International Publishers, I975), pp. 392-408, p. 407.

45 Cited in Lehning, Mikhail Bakunin, p. I9I-2. The reasons for which Marx and Bakunin came to different conclusions are complex; both were students of Hegel and worked within his dialectical tradition yet read him differently (see Robert M.Cutler, Mikhail Bakunin - from out of the Dustbin - Bakunin's Basic Writings, I869-7I [Michigan: Ardis, I985], as well as fn. $7 \mathrm{I}$ of the present work on this point. Bakunin's quarrel with Marx also arguably had much to do with elevating the revolutionary status of Slav peasants vs. German proletarians. While anarchist transnationalism cannot be reduced to a function of patriotism, Levy makes a valuable point: "Even if anarchists and anarchism are assumed to be anti-thetical to nationalism and national movements, they, like socialists and the ideology of socialism (and even Marxism) lived in close (one could say dialectical) relationship to both nationalism and the nation 
"only salvation in a revolutionary anarchy directed by a secret collective force": "We must direct the people as invisible pilots, not by means of any visible power, but rather through a dictatorship without ostentation, without titles, without official right, which in not having the appearance of power will therefore be more powerful." ${ }^{46}$

The "dictatorial power" of this secret organization only represents a paradox if we do not recognize the long tradition, and larger cosmology, within which Bakunin is working. Revolution may be "immanent" in the people, but the guidance of illuminated men working in the "occult" was necessary to guide them in the right direction. Members of his International Brotherhood were to act "as lightening rods to electrify them with the current of revolution" precisely to ensure "that this movement and this organization should never be able to constitute any authorities". ${ }^{47}$

\section{Theosophy, the Dialectic, and Other Esoterica of 19th Century Socialism}

Beyond Bakunin himself, Robert Owen (I77I-I 858), Charles Fourier (I772-I 837) and Saint-Simon (I760-I825) are also often cited as forefathers in standard histories of anarchism..$^{8}$ The Owenites were distinctly anticlerical, attacking all forms of "religion", but Owen himself was a spiritualist in admiration of Emmanuel Swedenborg (I688-I772), who taught the arrival of an "internal millennium". The first Owenite communes in America were based largely on Swedenborg's teachings. ${ }^{49}$ Charles

state" (Carl Levy, "Anarchism, Internationalism and Nationalism in Europe, I 860-I939." Australian Journal of Politics and History [2004, 50, 3, pp. 330-342], here pp. 33I). For further analysis of the rivalry between Marx and Bakunin in the IWA see Braunthal, History of the International; Wolfgang Eckhardt, The First Socialist Schism: Bakunin vs. Marx in the International Working Men's Association, (CA: PM Press, 2016).

${ }^{46}$ Bakunin cited in Saña, El anarquismo, p. Io6.

47 Bakunin cited in Robert M. Cutler, Mikhail Bakunin, p. 28.

$4^{8}$ See e.g. Bose; Marshall; Woodcock; fn. 6 of present work.

49 See e.g. Alfred J. Gabay, The Covert Enlightenment-Eighteenth Century Counterculture and Its Aftermath (West Chester: Swedenborg Foundation 
Fourier, for his part, based his political project on what he called the Law of Passional Attraction - a series of correspondences in nature that maintain harmony in the universe and could be applied to human society. ${ }^{\circ}$ Saint-Simonians aimed at reforming existing institutions, but Fourierists and Owenites rejected the existing system altogether. Rather than a mere "changing of the guard", they advocated the creation of new forms of independent organization within the existing system; hence their "precursor" status to anarchism, perennially defined by the notion of building a new world within the shell of the old, whether via "networks", communes or syndicates, and primarily defined by its rejection of state power.

Darwin's treatise on evolution also lent itself to theories of social change that dovetailed with revolutionary thought - a distinction between evolution and revolution in $19^{\text {th }}$ century utopian socialism would be rather forced. The insight that the natural world was characterized by evolving beings blended easily with the concept of cosmic regeneration - adaptive "process" became "progress", a tendency toward perfection. Indeed many extended the idea from plants and animals to human society, the most famous version of such a move being "Social Darwinism", traceable to Herbert Spencer who was the actual author of the phrase "survival of the fittest" ${ }^{5}$ Here Darwin is recuperated within the transcendentalist tradition to lend weight to the Hobbesian conception of the state of nature - the "war of each against all" convenient to capitalist ideology. Anarchist natural philosophers of the $19^{\text {th }}$ century read Darwin differently. Piotr Kropotkin posited "Mutual Aid" as a prime "Factor of Evolution" (I9I4), which we ourselves can manifest as we lead civilization toward egalitarian harmony. ${ }^{52}$ It is also worth noting that Kropotkin's key

Publishers, 2005), pp. xiv, I 53-4; Frank E. Manuel and Fritzie P. Manuel, Utopian Thought in the Western World (Cambridge: Harvard University Press, I979), p. 585 .

50 See Manuel and Manuel, chapter 27.

${ }^{5}$ See Charles Darwin, On the Origin of Species. (Cambridge: Harvard University Press, I964 [I859]); Herbert Spencer, Principles of Biology. (London: William and Norgate, I 864).

52 Piotr Kropotkin, Mutual Aid: A Factor of Evolution (Boston: Extending Horizons Books, I955 [I9I4]). 
contribution to anarchist theory was heavily influenced by Mechnikov, who was in turn inspired by a long stint in revolutionary Japan, and who had written of the world being divided into three spheres - inorganic, biological and sociological, each governed by its own set of laws but with enough correspondences between them that human society could be read as a continuously evolving expression of a unified whole..$^{53}$

The theosophy of Helena Pavlova Blavatsky (I83I-I89I), which intrigued many anarchists, involves a teleology of divine evolution represented by successive "root races" and whose finality was cosmic union. ${ }^{54}$ Leo Tolstoy (I 828-I9IO), a Theosophist and anarchist himself, also admired Fedorov (I 828-1903) who wrote that the common task of humanity was to use science to resurrect its dead fathers from particles scattered in cosmic dust. 55 Chulkov, Berdyaev and Ivanov, contemporaries of both Fedorov and Tolstoy during the Russian occult revival, all posited a "mystical anarchism" that equated political revolution with realignment in the cosmic sphere. ${ }^{56}$ In England, union organizer and early

53 See Sho Konishi, 'Reopening The "Opening of Japan": A RussianJapanese Revolutionary Encounter and the Vision of Anarchist Progress', American Historical Review, II 2 (2007), IOI-30, as well as his monograph, Sho Konishi, Anarchist Modernity: Cooperatism and JapaneseRussian Intellectual Relations in Modern Japan. (Cambridge: Harvard University Press, 2013).

54 Find Blavatsky's theory in Helena Pavlova Blavatsky, 'An Abridgement of the Secret Doctrine', ed. Elizabeth Preston and Christmas Humphreys (Illinois: The Theosophical Publishing House, I966).

55 See Leo Tolstoy, "The Kingdom of God is Within You: Christianity Not as a Mystical Doctrine but as a New Understanding of Life", in The Kingdom of God and Peace Essays, (New Delhi: Rupa, 200I), as well as discussion in Christoyannopoulos and Apps, Anarchism and Religion. Regarding the 'anarchist religion' inspired by Tolstoy in Japan, see Konishi (2013). Regarding Tolstoy and the occult revival in Russia see also Bernice Glatzer Rosenthal, 'Introduction', in The Occult in Russian and Soviet Culture, Ed. Bernice Glatzer Rosenthal (Ithica and London: Cornell University Press, I997), II, 22; James Webb, The Occult Establishment, (Illinois: Open Court Publishing, I976) I 57, I74-5.

${ }^{56}$ See Bernice Glatzer Rosenthal, 'Political Implications of the Early Twentieth-Century Occult Revival', in The Occult in Russian and Soviet Culture, ed. Bernice Glatzer Rosenthal (Ithica and London: Cornell University Press, I997), pp. 379-4I 8 (p. 382); Webb, I96. 
feminist Annie Besant, who organized women match-makers and fought to open the Masonic lodges to women, was convinced she was the reincarnation of Giordano Bruno, and it was Theosophy that inspired her to fight for Home Rule in India, as well as how she met Jawaharlal Nehru, himself a member of the Theosophical Society. ${ }^{57}$ Just as socialists were attracted to the occult, spiritualists and mediums of all kinds, who were disproportionately women, were led by their spiritual views to engage the "social question". ${ }^{8}$

Further examples from the anarchist diaspora include the story of Greek utopian socialist Plotino Rhodakanaty, often credited as being the first European "proselytizer" of anarchism to arrive in Mexico, whose first task upon arrival was to draft pamphlets titled Neopanteísmo ( I 864) while working with Julio Chávez Lopez to foment uprisings in the Chalco valley, after which he founded the Escuela del Rayo y del Socialismo, (which translates, somewhat ungracefully, as 'School of Socialism and Lightening' [and/or] 'the Ray' ['of Light']). ${ }^{59}$ Rhodakanaty later went on to form La Social, a 62-branch network of agitators in contact with the IWA, who formed Falansterios Societarios in indigenous communities. ${ }^{60}$ Fifty years later, the politics of Ricardo Flores Magón (I874-I922) were immortalized in his newspaper titled Regeneración, while his comrades called each other

57 Andrée Buisine, 'Annie Besant, Socialiste et mystique', Politica Hermetica, 9 (I995); Peter van der Veer, Imperial Encounters - Religion and Modernity in India and Britain (Princeton: Princeton University Press, 200I), chapter 3 .

${ }^{8}$ Nicole Edelman, 'Somnabulisme, Médiumnité et socialisme', Politica Hermetica, 9 (I995). See also Claudio Lomnitz, The Return of Comrade Ricardo Flores Magón. (New York: Zone Books, 20I4), pp. 3I-7, 27I-5).

59 Inspired by Spinoza, Hegel, Fourier and Proudhon, Rhodakanaty called his political pantheism "pantheosophy"; see John Hart, Anarchism and the Mexican Working Class, I860-I93I (Austin: UT Press, I978, here pp. I9-20); Angel Cappelletti, "Prólogo y cronologia - Anarquismo Latinoamericano." In El Anarquismo en America Latina, edited by Carlos and Angel Cappelletti Rama (Caracas: Biblioteca Ayacucho, I990, pp. ix-ccxvii; here p. clxxvii); Carlos Illades, Rhodakanaty y la formación del pensamiento socialista en México (Rubi: Anthropos, 2002).

60 See John Hart, Anarchism and the Mexican Working Class, Chapter I. 
"co-religionaries". ${ }^{6 r}$ Further south, Augusto César Sandino of Nicaragua (who later became the icon of the 'Sandinista' revolution in the I970s and I980s), was enthralled by the Magnetic-Spiritual School, Theosophy, and Zoroastrian, Hindu and Kabbalist lore, fusing all these ideas together with communist ones in such a way that he was refused entry to the Third International as a consequence - they had heard rumours that he flew a seven-striped rainbow flag alongside the red and black. ${ }^{62}$ I could go on, but do not have the space to treat so many complex stories of diverse colonial encounters with the attention to specificity they deserve. I merely present these few suggestive examples to remind us that the cross-pollinations of diverse cosmologies underlying modern revolutionism does not necessarily stop, and perhaps find only their latest expression, in present-day anarchists' selective fascination with indigenous cultures and cosmologies. ${ }^{63}$

61 On Magón's Partido Liberal Mexicano (PLM) and its relationship with syndicalist movements and transnational anarchist organizing see e.g. Lomnitz, Cappelletti, and Hart (cited previously) as well as Ruben Trejo, Magonismo: utopia y revolucion, I9IO - I9I3. (Mexico, D.F.: Cultura Libre, 2005), Javier Torres Parés, La Revolución sin Frontera: el Partido Liberal Mexicano y las relaciones entre el movimiento obrero de México $y$ de los Estados Unidos, I900-I923 (Ediciones Hispánicas, I990); and Eduardo Blanquel, "El anarco-magonismo." Historia Mexicana (I3 [3], pp. 394-427, I964). Lomnitz in The Return of Ricardo Flores Magon provides a unique ethnographic entry into the political culture and everyday life of the PLM and the Regeneración press; the reference to "coreligionaries" cited above is taken from a letter co-written by Ricardo Flores Magon which is itself titled "To Esteemed Friend and Correligionary", February I I, I904, cited in Lomnitz (pp. I98). Lomnitz also discusses Freemasonry in connection with the Mexican revolutionary movement (pp. 96-7), as well as the influences of Theosophy and Spiritism among PLM members.

62 See Donald Hodges, Sandino's Communism - Spiritual Politics for the Twenty-First Century (Austin: UT Press, I992), chapter 6.

${ }_{63}$ I explore contemporary anarchist solidarity campaigns with indigenous peoples movements in a more critical vein in Erica Lagalisse, "Good Politics": Property, Intersectionality, and the Making of the Anarchist Self" (PhD diss., McGill University, 20I6); see especially Chapter 3: "anarchism's peasants and indigenous people fill a certain 'savage slot'.. . that has always served to justify anarchist politics whether or not real peasants or indigenous people are liberated in the process" (I37). See also e.g. K. Johnson and K. E. Ferguson, "Anarchism and Indigeneity" 
Not every anarchist was a theosophist or enamoured with the occult. Emma Goldman, for example, wrote an entirely scathing account of Krishnamurti's arrival in America as the supposed Theosophical avatar. ${ }^{64}$ However, the fact that Goldman's Mother Earth and a variety of other anarchist periodicals bothered to criticize Theosophy at all should tell us something - nothing is forbidden unless enough people are doing it in the first place. Even the sceptics often grudgingly recognized that they were kindred spirits. As anarchist C.L. James wrote in I902: "However ill we may think of [Swedenborgian] dogmas, their influence is not to be despised. They have insured, for one thing, a wide diffusion of tendencies ripe for Anarchistic use. Scratch a Spiritualist, and you will find an anarchist." ${ }_{65}$ Indeed it was none other than the president of the American Association of Spiritualists that published the first English translation of The communist Manifesto in I $872 .{ }^{66}$

We can imagine how much this annoyed Marx. But Marx's anticipation of a Communist millennium after the overthrow of capitalism, brought about by a mixture of wilful effort and inbuilt cosmic fate, isn't actually that different from the idea of the unfolding New Age. The major difference, and the one that prompted Marx and Engels' to distinguish their utopian vision as "scientific" compared to the others, was their notion of the dialectic, which preserved the form, if not content, of the Hegelian one. ${ }^{67}$

in The Palgrave Handbook of Anarchism, Eds. C. Levy, M. S. Adams, (Basingstoke: Palgrave Macmillan, 20I9), for contemporary discussion (construction) of affinities between "anarchism" and "indigeneity".

${ }^{64}$ Cited in Veysey, The Communal Experience - Anarchist and Mystical Counter-Cultures in America (New York and London: Harper and Row, I973), p. 45-6.

${ }^{6}$ C.L. James, Origins of Anarchism (Chicago: A. Isaak, I902), cited in Veysey.

${ }^{66}$ see Bernice Glatzer Rosenthal, "Introduction.” In The Occult in Russian and Soviet Culture, edited by Bernice Glatzer Rosenthal, (Ithica and London: Cornell University Press, pp. I-34, I997), here p. 22.

${ }_{67}$ See e.g. Karl Marx, 'The German Ideology', in The Marx-Engels Reader, ed. Robert Tucker (NY: W. W. Norton \& Company, [I932] I978), pp. I46-200 (p. I 54); and Capital Vol. I (London: Penguin, I990 [I876]), especially pp. 494 , fn. 4 . 
Hegel's dialectic cast history as a dynamic manifestation of the Idea, the unfolding of consciousness itself, in which everything is but a mode and attribute of a single universal substance. ${ }^{68}$ Meanwhile Hegel's Logic (I8I2) features an obsession with emanation and return by way of neat geometrical constructions of all kinds, while in his Phenomenology of Spirit (1807), the Idea issues in nature, which issues in Spirit, which returns to Idea in the form of Absolute Spirit. ${ }^{69}$ Marx breaks with Hegel in conceiving consciousness as inextricable from material social processes, rather than as a first premise, however the material and the ideal remain indissoluable, his logic is dialectical, and the eschatology of his historical dialectic can be traced back to Joachim de Fiore as much as Hegel's can. While one of the main defining attributes of anarchism is its anti-Marxism, many Hermetic features of Marxist thought remain preserved (as abstract content) as well as transcended within anarchism's concrete form. ${ }^{70}$

${ }^{68}$ Certain 'non-metaphysical' readings of Hegel aside, it is commonly noted that Hegel's philosophy is pantheistic (or monist, as opposed to dualist), following Spinoza; see e.g. Frederick Beiser, Hegel (London: Routledge, 2005 ).

69 I follow Glenn Alexander Magee, Hegel and the Hermetic Tradition (Ithica and London: Cornell University Press, 200I): Regarding Hegel's subject/object consider Corpus Hermeticum I4, "for the two are all there is, what comes to be and what makes of it, and it is impossible to separate one from the other"; likewise, with Hegel's dialectic of desire and recognition in mind, consider Corpus Hermeticum IO: "For God does not ignore mankind; on the contrary, he recognizes him fully and wishes to be recognized." ; see Copenhaven, pp. 56, 33; Georg Wilhelm Friedrich Hegel, Phenomenology of Spirit. trans. A. V. Miller (Oxford: Clarendon Press, I977 (I807)). Hegel's system of logic is a triad, each further divided into three chief moments, analyzed in turn into three other constitutive moments, which are split in turn into another three; see Georg Wilhelm Friedrich Hegel, The Science of Logic. trans. George Di Giovanni (Cambridge: Cambridge University Press, 20Io (I8I2)). As Magee writes, “The dove of [Hegel's] Spirit emerges from a God-created nature, and circles back to God" (pp. 2I2). see also Magee, chapter 7 . Regarding Hegel's relationship with Freemasonry see Susan Buck-Morss, 'Hegel and Haiti' in Critical Inquiry, Vol 26., No. 4 (summer 2000), pp. $82 \mathrm{I}-865$.

70 Marx distinguished his dialectic from that of Hegel as being materialist rather than Idealist, yet in both of their systems the resolution of the dialectical contradiction comprehends not only the destruction and 
The fact that Marx builds on Hegel who builds on the Hermetica does not necessarily mean they are wrong; it simply means that a vast amount of "rational" social theory relies on archetypes and geometries of thought stemming from a specific, historically situated cosmology - as does the notion of "rationality" itself. ${ }^{7 \text { I }}$

Socialism and occultism developed in complementary (as well as dialectical) fashion during the $19^{\text {th }}$ century, yet the cosmological grounding of $19^{\text {th }}$ century anarchists' politics is generally downplayed, or treated as epiphenomenal, in retrospect: Just as

transcendence of the thesis by the anti-thesis but also its preservation. In Bakunin's system, the Positive and the Negative destroy one another entirely, leading to the transcendence of both and preserving nothing. Bakunin established the Negative as the motive force of the dialectic as opposed to Marx and Hegel whose dialectic began - and ended - with the Positive (thesis). Insomuch as Hegelian philosophy informed the political analyses and calls to action of each Marx and Bakunin, here we can see one of the reasons they parted opinion over the role of the state. Bakunin sociomorphized the Positive into Social Reactionaries and the Negative into Social Revolutionaries; the state, as part of the (Positive) old order, would be destroyed and transcended entirely by the social revolution; no aspect of the existing society, including the state, would survive the insurrection. Both Marx and Bakunin believed that Democracy was the motive force of history, the real form of Hegel's world-historical Spirit. They also agreed with Hegel that Monarchy was the generic form of the state. For Bakunin, this meant that "the State had to be destroyed in a general conflagration. For Marx, however, the essence of the State was Democracy itself; he conceived Democracy to be embodied in a constitution hierarchically superior to other political forms, and therefore concluded that the State had to be realized to its highest degree" (2I, author's emphasis). See Cutler, Mikhail Bakunin, for further discussion, especially pp. I8-2I, here pp. 2I)

${ }^{7 r}$ Beyond the discussion presented here, the reader may wish to consult the following in regard to the (co)construction of "secularization", "rationality", "science”, “magic", and "religion": Peter Gay, The Enlightenment: An Interpretation (New York: Knopf, I966); Keith Thomas, Religion and the Decline of Magic: Studies in Popular Beliefs in Sixteenth and Seventeenth Century England (New York: Penguin, I982); Owen Chadwick, The Secularization of the European Mind in the Nineteenth Century (the Gifford lectures in the University of Edinburgh for 1973-4), (Cambridge: Cambridge University Press, I975); as well as Talal Asad's Formations of the Secular, and Gil Anidjar's Secularism, cited earlier. My strongest recommendation would be to begin with Stanley Tambiah's Magic, Science, Religion and the Scope of Rationality (Cambridge University Press: Cambridge, I990). 
Newton's Alchemy is largely ignored in mainstream histories of the establishment, so Fourier's Law of Passional Attraction is rewritten in mainstream histories of the Left as a vision of "a harmonious society based on the free play of passions" ${ }^{72}$ It was only when Marxist "scientific socialism" became hegemonic during the $20^{\text {th }}$ century that the theological understandings of modern revolutionism were buried from consciousness among the popular and academic Left. ${ }^{73}$ During this past century, whenever occult philosophy has been dealt with in its own right, it has generally been cast as "comforting" in anxiety-provoking periods of social change, or, in certain Marxian style, as a product of capitalist alienation. In Adorno's Theses against Occultism (in which he makes ample use of Hegel, somewhat ironically), occultism is both a 'primitive' holdover and a consequence of 'commodity fetishism' at once, in a typical circular (and colonialist) argument that suggests the occult worldview is wrong because it is animistic and vice versa a "regression to magical thinking". ${ }^{74}$ E.P. Thompson, for his part, characterized the working class as "oscillating" between the "poles" of religious revivalism and radical politics. ${ }^{75}$ Over and over, occult philosophy is portrayed as either inducing apathy among the masses or as the territory of elite reactionaries who stir them to hatred, rather than having any connection to socialism, communism, or anarchism. The symbiosis of Blavatsky's Theosophy with eugenics, and the association of occult narratives

${ }_{72}$ See Marshall, pp. I49.

73 The complex historical reasons why certain currents of Marxism vs. anarchism became more widespread during the $20^{\text {th }}$ century will be bracketed here, yet note that contributing factors are necessarily overlapping and debatable, with explanations ranging from Eric Hobsbawm's (in Primitive Rebels) which beholds scientific Marxism progressively replacing the more "primitive" anarchism, to Graeber's which highlights how the centralizing logic of state Marxism was practical during the $20^{\text {th }}$ century of global war (see David Graeber, "The New Anarchists" in New Left Review, I3, 2002, pp . 6I-74, here pp. 69); it is of course impossible to provide a scholarly analysis (representation) in this regard that is not also a (material) political position - Marxists and anarchists can agree on this particular point.

74 Theodor Adorno, 'Theses against Occultism', TELOS, I9 (I974), p. 8.

75 E.P. Thompson, The Making of the English Working Class (NY: Vintage, I963), p. 39I. 
and iconography with the rise of fascism, for example, are often pointed out, and of course the connections are there. ${ }^{76}$ The ideas offered within occult philosophy do not necessarily lead to revolutionary politics, but they do not necessarily lead away from them either. When regarding the relationship of "magic" to anti-systemic movements, perhaps any deterministic formula is bound to fail. When approached by privileged persons with a lust for power, "magic" can serve to justify and advance elite aspirations. But without the influx of so much material charged as "ancient magical wisdom" that helped triangulate popular religion,

${ }^{76}$ See e.g. Nicolas Goodrick-Clarke, The Occult Roots of Nazism: Secret Aryan Cults and Their Influence on Nazi Ideology: The Ariosophists of Austria and Germany, I890-I935, (NY: New York University Press, I992). Regarding the historical link between occultism and Nazism it is key to understand that at the turn of the 2oth century (I903), the global capitalist oligarchy was blamed on a secretive group of Jewish patriarchs (in turn associated with Masonry and magic) in a Russian forgery titled "The Protocols of the Elders of Zion", which was widely distributed in decades following (Henry Ford himself distributed 500,000 copies); see Victor E. Marsden, ed. The Protocols of the Elders of Zion, (Filiquarian Publishing LLC, 2006); R.S. Levy, A Lie and a Libel: The History of the Protocols of the Elders of Zion. (University of Nebraska Press, I995); Norman Cohn, Warrant for Genocide: The Myth of the Jewish WorldConspiracy and the Protocols of the Elders of Zion (New York: Harper \& Row, I966). The reader may also note that one of the influential books to associate "revolutionism" (from the French Revolution to the Bolshevik Revolution) with a similar secretive directing force was Secret Societies and Subversive Movements (London: Boswell, I936) by Nesta Webster, which relied heavily on the Protocols. There also existed works during this time period that did not partake of this specific view of history, yet wherein anti-Semitism nonetheless defines the analysis, such as Mircea Eliade's The Myth of the Eternal Return - or, Cosmos and History (Princeton: Princeton University Press, I974 [I949]), wherein the linear, redemptive history that has displaced (true) understanding of cyclical time is associated with Judaism. For an analysis of anti-Semitism with respect to the Saint-Simonians see Zosa Szajkowski. I947. "The Jewish Saint-Simonians and Socialist Antisemites in France." Jewish Social Studies 9 (I):33-60; compare with Moya, José. 2004. "The positive side of stereotypes: Jewish anarchists in early twentieth-century Buenos Aires',.” Jewish History I 8 (I): pp. I9-48; Levy, Carl. 20I I. "Anarchism and cosmopolitanism." Journal of Political Ideologies I6 (3):265-278. See Nesta Webster, Secret Societies and Subversive Movements (London: Boswell, I936). 
modern materialism and social discontent in new ways, we may never have seen the rise of "anarchism" as we know it. Even this quick glance at the history of revolutionism problematizes any simplistic dichotomy of New Age spirituality as reactionary (in both the senses of conservative and right-wing), vs. a materialist worldview as progressive (in both senses of forward-looking and leftist). Rather, secularized and "scientized" religion appears inherent to modern anti-systemic critique and collective action - the West's attempt to save itself from its impoverished materialism through an enchantment "newly reconfigured". ${ }^{77}$ The world did not have to be "disenchanted" before modern anti-authoritarianism could occur, it had to be re-enchanted: A rejection of material exploitation, "materialist values" and materialist philosophy appear as three sides of the same coin.

\section{To Conclude (and to Begin Anew...)}

As I explained at the outset, I began this project partly in order to clarify how the "atheism" professed by those working in the Western anarchist tradition intersects with colonialism, as well as embodies a serious misunderstanding of the history of anarchism itself. In my previous ethnographic work, I had argued that maintaining a neat dichotomy between "spirituality" and "radical politics" only makes sense within a colonialist rubric wherein the religious Other becomes the constitutive limit of the "rational West". The subsequent reception of my work by both academics and anarchists has beheld a certain pattern: Many anarchist activists and scholars agree that we should indeed be more "respectful" of "indigenous identity". This, even though I had taken care to emphasize that the operative problem goes beyond a failure to be sufficiently polite in the presence of difference. Beyond being "disrespectful", insisting on a disenchanted universe delimits the radical imaginary in general. To refrain from telling the non-atheist activist they are wrong (while continuing to think they are), simply because he or she is a person of colour, is really very different

77 See Thomas Laqueur, 'Why the Margins Matter: Occultism and the Making of Modernity', Modern Intellectual History, 3 (2006), I I I-35 (pp. I I I-I 2); Webb also makes this point, p. 344-45. 
than self-critically deconstructing one's colonial mentality that treats the religious as Other in the first place. ${ }^{78}$

Keeping this question in mind, I wonder what the eighteenth and nineteenth centuries in Europe would have looked like if militants regarded culture as property the way many anarchists and indigenous people do today. Certainly the "occult" history of anarchism that I present above could be analysed in terms of Orientalism, and of course the cross-cultural dialogues among heretics during the Crusades happened in the context of complex power relations. ${ }^{79}$ At this time, however, it was not yet clear who would emerge as the dominant party. Is Kropotkin's Mutual Aid "culturally appropriated" because he was inspired by Japanese revolutionaries? Perhaps insofar as we don't know about it, in combination with the fact that there is now money to be made off Kropotkin-related-commodities. However, reading a concept like "cultural appropriation" on to the past would falsely assume that the fields of meaning and value at the time can be equated to those inflecting today's self-making projects: During the Renaissance "difference" did not have the same currency, and people were not ascribed the same identities nor "self-identified" according to the categories in play now. It makes sense that a critique of cultural appropriation emerges in the present-day context, wherein cultural difference is fetishized and certain people may valorise themselves by accessorizing commodified attributes of those they

${ }^{78}$ See Lagalisse, Marginalizing Magdalena, for my first rehearsal of this argument with reference to Talal Asad, Formations of the Secular Christianity, Islam, Modernity (Stanford University Press: California, 2003), Gil Anidjar (cited earlier), Joan Scott "Sexularism”, RSCAS Distinguished Lectures, Florence, Italy, April 23, 2009, Gloria Anzaldúa, Borderlands - La Frontera. San Francisco: Aunt Lute, I987), and Jacqui M. Alexander, Pedagogies of crossing: Meditations on Feminism, Sexual Politics, Memory, and the Sacred, (Durham: Duke University Press, 2005 ), among others - it is perhaps no coincidence that in the 'memory' of Jacqui Alexander, "everything is interconnected”. See Lagalisse, Good Politics, Chapters 7-9, for an in-depth discussion of non-performative white anti-racisms among anarchists, and the "insult of courtesy" that may characterize praxes of "anti-oppression".

See Edward Said, Orientalism, (NY: Vintage, I978).

79 See Edward Said, Orientalism, (NY: Vintage, I978). 
structurally oppress, but we may also lose something in the process of applying the logic of property to culture, and to spirituality in particular. ${ }^{80}$ When entire cosmologies are reified as "proper" only to specific pre-ordained identities, we are effectively saying they are false to the extent that they do not apply across the cosmos whatsoever. The sacred is thus rendered as alterity, nothing more than a cultural accoutrement in a marketplace as big as the universe. Appropriating indigenous spiritual forms without the intended content is entirely in line with the logic of capitalist colonialism, but so is marking off and containing everything considered sacred as property (and thus nothing more). ${ }^{81}$

In other words, the fact that anarchists are often unable to recognize the subversive potential of religious sensibilities - whether those of indigenous women or Bakunin himself - is disturbing beyond anarchists' failure to respect the "difference" or the "identity" of others, and to recuperate such a debate within the parameters

$8 \circ$ For discussion of cultural appropriation in this vein see Beverley Skeggs, Class, Self, Culture, (London: Routledge, 2004.)

${ }^{81}$ Readers in anthropology might consider how the disciplinary "ontological turn" could be read similarly, wherein the anthropologist (finally) grants the "reality" of plants that think, clouds that have agendas, and spiritual animal protectors, but only by inventing multiple realities in the process: ontology (reality) becomes plural such that the white man can still enjoy his office without having to worry about the weather; see, e.g. David Graeber's “Radical alterity is just another way of saying 'reality': A reply to Eduardo Viveiros de Castro" Hau - Journal of Ethnographic Theory, Vol 5, No 2 (20I 5), and Zoe Todd's “An Indigenous Feminist's Take On The Ontological Turn: 'Ontology' Is Just Another Word For Colonialism' Journal of Historical Sociology, Volume 29, Issue I (20I6). Regarding the 'sacred', following Durkheim (The Elementary Forms of Religious Life, London: George Allen \& Unwin Ltd, 2008 [I9I2]) who built his theory around the "totem", the sacred is, by definition and universally, something "set apart”. Rejoinders such as Asad's Formations of the Secular locate the "sacred" as a specifically Judeo-Christian concept. In either case, while most peoples throughout history do create categories of things, people, and ideas that are set apart from the mundane in some form, I here refer to the specific divisibility of the material and the 'sacred' that occurs through processes of commodification and reification; see, e.g., Andrea Smith, Conquest - Sexual Violence and American Indian Genocide. (Cambridge: South End Press, 2005), Chapter 6; Gloria Anzaldúa, Borderlands - La Frontera. (San Francisco: Aunt Lute, I987), pp. 68-9, passim. 
of "identity" and attendant proprieties is arguably racist in and of itself. Rather, we must actually consider the synergistic relationship between spirituality, faith and radical political movements, whether in present-day Latin America or $19^{\text {th }}$ century Europe, up to and including the original "New Age movement" itself from whence modern anarchism came.

In so doing, we also appeal to anarchists who do not take a hard atheist stance, yet who feel the need to hide their various spiritual inclinations in officially Left-wing spaces: whereas at the turn of the $20^{\text {th }}$ century it was possible to say "Scratch a Spiritualist, and you will find an Anarchist", a hundred years later the tables have been turned. Other things haven't changed that much - a zine an activist acquaintance of mine published in 2013 is titled "Anarchism and Hope" wherein he advises: "Fuck waiting on on someone else or some divine force to change shit. Hope means we can see how to do it ourselves." ${ }^{2}$

I also suggested in my introduction that the story told here is important to reflect on because while the patriarchal bias of classical anarchist theory and practice is often noted in reference to its genesis in male proletarian workers' movements, the gendered quality of "anarchism" is arguably more fundamental than that. The masculine public sphere of anarchism reaches back even further, and articulates with an occult cosmology that is older still. As anti-systemic resistance in Europe shifted from the millenarian mode to modern socialism, the biggest difference was not, in fact, that the former was "religious" and the latter wasn't, but rather that in the latter the paradise of heaven would be manifest on the earth, and through the works of men not God - or indeed, men as God - and that it was the job of a chosen few who had access to "ancient spiritual wisdom" circulating in new secret male orders to inspire them to action. To simply argue now that "real" anarchism is by definition feminist as well insomuch as anarchism is "against all forms of domination" does not engage the ways in which the anarchist revolutionary person was constructed vis-àvis a variety of exclusions from the outset, especially insomuch as

${ }^{82}$ see Aaron Lakoff, Anarchism and Hope, Howl! arts collective, Montréal, Québec, 20I3. 
these continue unmediated by a certain unacknowledged "vanguardism": Revolution may be immanent in the people, but as any $2 \mathrm{I}^{\text {st }}$ century anarchist around can see, fluency in a particular vocabulary, knowing the names of certain historical figures, and being vouched for by someone in the know is all requirement for entry into the anarchist club, as is a commitment to a specific ideological constellation informed by the history of its practice, wherein men's oppression by the state becomes the prototype for power in general.

I may be forcing an analogy by saying that all of this social and subcultural capital resembles the "opaque system of signs" of $19^{\text {th }}$ century initiatic societies, but the (hidden) correspondence is worth reflecting on. ${ }^{83}$ Similarly, unless we narrowly define "vanguard" to mean "political party" per se, the common notion among present-day anarchist activists that Marxists are "vanguardist", whereas anarchists are not, does not bear scrutiny. Anarchists have always considered themselves purveyors of particular insight, and continue to join social movements and the general fray to steer it all in a more revolutionary direction. ${ }^{84}$ My point is not to criticize such a practice, but to suggest that its disavowal and dissimulation within discourses of "solidarity" may be disingenuous. ${ }^{85}$ While anarchists today carefully skirt the phrase "consciousness raising" (it sounds too Marxist), their

${ }_{83}$ See Lagalisse, Good Politics, Chapter 6, for a lengthier discussion on this point and in regard to the changing forms of clandestinity characterizing the Left from the I9th to the 2ist century.

${ }^{8}$ To offer just one contemporary example, anarchists participated in the Occupy movement (2OII), despite its observed "reformist" aspects, to prevent it veering in a racist and nationalist direction, and to steer it towards a liberatory politics; see e.g. Erica Lagalisse, "Participación e influencias anarquistas en el movimiento 'Occupy Wall Street'.” Periodico del CNT (Confederación Nacional del Trabajo), $\mathrm{n}^{\circ} 383$, noviembre $20 \mathrm{II}$.

${ }_{5}$ For further discussion in this vein see Lagalisse, Good Politics - Anarchist activists in the North America today often articulate their actions and ideology as "taking lead" from indigenous activists or other marginalized groups of people, yet they are also working within a tradition of their own. 
various workshops on "anti-oppression" appear to have precisely such a purpose: Why so much self-deception? ${ }^{86}$

Similarly, it should also be significant that today's anarchist intellectuals generally do not cite indigenous women scholars such as Audra Simpson when they are mounting their compelling arguments against the State: Theirs are not the code words for belonging. ${ }^{87}$ Rather, anarchist activists and scholars who are interested in questions of "sovereignty" often prefer to peruse the work of Giorgio Agamben who, much like Carl Schmitt, brackets gender and race by proceeding as if one can equate "human being" and "male citizen of Rome or France". ${ }^{88}$

${ }^{86}$ See Lagalisse, Good Politics, Chapter 8, with respect to current discourses and praxes of "anti-oppression".

${ }_{7}$ See e.g. Audra Simpson, Mohawk Interruptus - Political Life Across the Borders of Settler States (Durham and London: Duke University Press, 20I4).

${ }^{88}$ I refer to Giorgio Agamben's Homo Sacer - Sovereign Power and Bare Life, (CA: Stanford University Press, I998), and Schmitt's Political Theology cited earlier. Agamben presents the inclusion/exclusion of "bare life"/sexuality as fundamental to classical-then-modern politics without reference to gender, yet indulging de Sade and with prime reference to Foucault. The Holocaust concentration camp is presented as epitome of the "sacredness" (murderability) of Life and modern bio/thanatopolitics by extension - Aimé Cesaire, author of Discourse on Colonialism (NY: Monthly Review Press, 2000 [I955]), turns in his grave. The prime contribution of Agamben's essay appears to be the crafting of a certain genealogy of ideas wherein knowledge is the sovereign domain of European male philosophers in contradistinction to feminists and black scholars of slavery: In his work these are definitively excluded from philosophy qua philosophy in perfect symmetry with how Roman/French women and slaves are excluded (as "bare life") from Agamben's own analysis. Note that Agamben's book The Coming Community (I993) was influential to The Invisible Committee's The Coming Insurrection (Paris: La Fabrique, 2007), which has enjoyed popularity among anarchist "insurrectionalists" in French, English and Spanish (among other presses). For a feminist response to The Invisible Committee/Tiqqun, see e.g. "Further Materials Toward a Theory of the Manchild" by Moira Weigel and Mal Ahern online at http://thenewinquiry.com/essays/further-materials-toward-atheory-of-the-man-child/. See also Audra Simpson's rejoinder to Agamben ". . .one does not have to dwell exclusively in the horror of a concentration camp to find life stripped bare to cadastral form. .." (Mohawk Interruptus, pp. I 53-4). 
It is not simply sexist reading habits that marginalize indigenous women scholars' work, but also the fact that their words are less easily recuperated within the European anarchist tradition, which has already decided that religion is bad and whose model of oppressive power is the state. For the indigenous women in Andrea Smith's ethnography, "sovereignty" is "an active, living process within this knot of human, material, and spiritual relationships bound together by mutual responsibilities and obligations"; Audra Simpson, for her part, points out the "critical language game" involved here: indigenous mobilizations of "sovereignty" are useful to signal "processes and intents to others in ways that are understandable". ${ }^{89}$ These remarks certainly sound different than the definitions of "sovereignty" advanced by Schmitt, described by Agamben, and critiqued by many anarchists, wherein sovereignty is always an (unmarked yet male) fantasy of absolute power via the state apparatus (and the practical project of consolidating this power as much as possible). But then again, why should Agamben or Schmitt be granted sovereign jurisdiction over the (power of) the Word? Indigenous women's mobilizations of "sovereignty" are not necessarily rhetorical, but even when they are, this where the (performative) magic happens. Following their lead could teach us all something about "sovereignty" that Schmitt, Agamben, and their anarchist readers fail to notice: European "sovereignty" has always involved subsuming women and children as property of

${ }^{89}$ Mohawk scholar Taiaiake Alfred contends that (native) "sovereignty" is premised upon Western notions of the nation-state, with its monopoly on violence and agendas of domination, yet Andrea Smith suggests we take lead from indigenous women activists who rather remark "sovereignty is not a foreign concept brought by the colonizers to Indigenous America. We are born as sovereign beings. Our struggle as sovereign peoples is to live the laws of creation."; see Andrea Smith, North Americans and the Christian Right, (Durham and London: Duke University Press, 2008), here pp. 260-I; Taiaiake Alfred, Wawáse - Indigenous Pathways of Action and Freedom (Toronto: Broadview Press, 2005). Audra Simpson is supportive of Alfred's point, yet analyzes the rhetorical politics involved in indigenous mobilizations of "sovereignty" (Mohawk Interruptus, pp. I05, passim). Note that while the status of Andrea Smith's indigenous identity is currently hotly contested, it is regardless significant that her work has also often been ignored. See Lagalisse, Good Politics, Chapter 9, for an analysis of the debacle over Andrea Smith's identity. 
male citizens whereas it is male citizens that are subsumed by the sovereign..$^{\circ}$ And furthermore, the male-philosophy slip between (legal) person and human being is also preserved in the anarchist response - "autonomy" ${ }^{9 \mathrm{II}}$ It is surely significant that the anarchist person is imagined as an independent, autonomous, and transcendent (sovereign) being that enters into "mutual aid" with others of its kind, much like the modern person writ large - the state. And that just as the state characterizes itself as benevolent to its citizens, the anarchist considers himself benevolent to the people (women) similarly subsumed in his "autonomy" and without whom he could not survive.

It should not be a surprise that anarchist academics ask me to authorize my texts by citing Carl Schmitt - they do want me to be accepted into the club, and kindly offer me the password. Neither should it be a surprise that reviewers suggest consecrating my work with the latest exegetical ruminations on St. Paul by Simon Critchley, whereas it is possible to get through ten years of doctoral studies regarding "anarchism" and only find out about Rosa Luxemburg afterwards, because of a book that happens to be laying on Barbara Ehrenreich's kitchen table: Anarchism has always been a gendered and racialized domain authorized by speculative elites as much as real builders. ${ }^{92}$ In my view, when it comes to

${ }_{90}^{\circ}$ I rehearse this argument at length elsewhere, with attention to LeviStrauss's work on the universalization and particularization at work in combinations of linear and taxonomic hierarchy, Louis Dumont's theory of hierarchy, and David Graeber's rejoinder regarding the exclusion as well as subsumption that is involved in hierarchical arrangements, which I adapt with reference to Macpherson's work on the 'possessive individual' (see Lagalisse, Good Politics, Chapter 9).

${ }^{9}$ En lieu of fantasies of absolute state power, "autonomy" involves a fantasy of absolute personal power that must presume a strict independence of individuals (or homogenous groups thereof), which must then be mitigated by a correlate call for "mutual aid" - the other side of the same coin. See Lagalisse, Good Politics, as well as Lagalisse (2018) for an in-depth discussion of this point, where I discuss how the anarchist ideas of autonomy, self-government, and self-management rely on the "self-organizing system" of modern life science, with reference to the work of Anna Tsing, The Mushroom at the End of the World - On the Possibility of Life in Capitalist Ruins. (NJ: Princeton University Press, 20I 5 ).

92 Simon Critchley's The Faith of the Faithless (NY:Verso, 20I2) does provide an in-depth analysis on the meanings of religion, sovereignty, and 
approaching things like "liberty" or "equality", the work of historian Jonathan Israel is more compelling than that of philosophers such as Agamben or Critchley, in my view, as Israel sets aside abstract propositions and instead works hard to "describe in the contexts of history and culture the actual emergence of these ideas". ${ }^{93}$ Perhaps the anthropologist is bound to favour historians such as Israel, yet by the same token is left wanting if contextual analysis does not comprehend the interesting (and productive) contradiction of ideas like "equality, democracy and individual liberty" actually emerging within new, secretive, status-restrictive, male-only clubs that are often referred to, rather curiously, as the modern "public sphere". How can so many of us pass over the (synchronic) gendered pairing of the Enlightenment Salon and Freemasonic Temple, or the (diachronic) gendered series of ("magical") witches and ("rational") brotherhood ceremonies, and yet claim to properly understand the form or content of the ideas of either? Not with recourse to the logic of 'history', whether that of Foucault or Hegel (or the Hermetica itself). It seems all 'earthly perspectives' are bound to be incomplete after all — including my own.

Let us now move to briefly discuss the "secret society". While I originally turned my scholarly attention to the cosmology of anarchism on account of my ethnographic research within anarchist and indigenous social movement collaborations, at a certain point during my research for this project I did consider it my specific responsibility to acquaint myself with the great flourishing of creative works concerning "secret societies" and "the Illuminati" to be found on YouTube throughout the past decade. It is clear that in the political and historical imagination corresponding to the majority of these works - popularly referred to as "conspiracy theories" — the 'Secret Order of the Illuminati' is understood to be a truly extraordinary

liberty in the work of Jean-Jaques Rousseau and Left thinkers who follow him, thus offering an argument around 'mystical anarchism' and faith that dovetails partially with my own; his own exposition advances by way of literature and logical propositions rather than an ethnographic social history. The book on Rosa Luxemburg I found on Barbara Ehrenreich's table (she had been asked to write a blurb for it) was Kate Evans, Red Rosa - A Graphic Biography of Rosa Luxemburg, (NY: Verso, 20I 5 ).

93 Israel, A Revolution of the Mind, pp. x. 
organization that has, among other things, achieved the ends of its historical enemy, the Holy Alliance, or the "conspiracy of kings".

It has also become clear during the same time period that most self-identified anarchist activists in North America dismiss the unsatisfying teleologies of such "conspiracy theories", especially those rife with anti-Semitic or otherwise racist narratives. ${ }^{94}$ Yet such narratives, increasingly prevalent, are arguably the very reason persons concerned with social justice should be paying attention. Respectable researchers may insist that diverse popular 'conspiracy theories' of power are laughably false, yet they apparently contribute to real political effects, such as the growing neo-fascist movements in North America, which are not laughable at all. Indeed given the evident charge and influence of the "conspiracy theory" in North America today - its forms and contents, as well as the powerful rhetorical functions of the (derogatory) discursive category itself, I suggest that anarchists consider engaging, mobilizing and qualifying the popular discontent evident in so-called "conspiracy theory". ${ }^{95}$ Anti-capitalists of all stripes would surely do well to tackle so much curious confusion regarding the Left and the Conspiracy of Kings, so many disturbing racialized political imaginaries, and so many 'bizarre' origin stories of capitalism often found within the works marked "conspiracy theory". We might critically analyse the genre in terms of allegory and archetype, narrative and imagery, voice and public, authorship and audience, for the express purpose of practical intervention. We might even explore, in the process, how both dominant powers and their "conspiracy theorist" critics make use of occult 'arts of memory' to compel their publics, and thus how the Hermetic tradition continues to inform both Right and Left in the

94 I offer a preliminary analysis of the social dynamics surrounding the "conspiracy theory" in contemporary anarchist social movement spaces in Erica Lagalisse," Anarchism and Conspiracy Theories in North America, or: The Conspiracy Theory as Antidote to Foucault", presented at the American Anthropological Association (AAA) Annual Meeting., Denver, CO, December 2015.

95 The final chapter of my upcoming monograph-length rehearsal of this work (Lagalisse 20I8), elaborates further on "conspiracy theory" as both an academic and practical political problematic, and explores the related question of occult(ed) arts of memory suggested briefly below. 
2 Ist century, albeit not in the way some "conspiracy theorists" may suspect. The pantheism I have discussed in these pages may indeed equally inspire the fantasies of fascism, the apocalypse of the dialectic, and the anarchist faith in an egalitarian social order. We would be wise to not ignore it, because now, as during the I9th century, as during the Renaissance period with which this essay began, the Hermetica proves 'adaptable to a variety of projects', including both pyramid and levelling schemes, as well as pyramid schemes for levelling - As Above, So Below.

\section{References}

Adorno, Theodor. 1974. 'Theses Against Occultism', TELOS, I9.

Agamben, Giorgio. I993. The Coming Community (University of Minnesota Press: MN).

- I998. Homo Sacer-Sovereign Power and Bare Life (Stanford University Press: Stanford).

Alexander, M. Jacqui. 2005. Pedagogies of Crossing: Meditations on Feminism, Sexual Politics, Memory, and the Sacred (Duke University Press: Durham).

Alfred, Taiaiake. 2005. Wawáse - Indigenous Pathways of Action and Freedom (Broadview Press: Toronto).

Anidjar, Gil 2006. 'Secularism', Critical Inquiry, 33: 52-76.

Anzaldúa, Gloria. 1987. Borderlands - La Frontera (Aunt Lute: San Francisco).

Asad, Talal 2003. Formations of the Secular - Christianity, Islam, Modernity (Stanford University Press: California).

Bakunin, Mikhail I970. 'God and the State.' in Paul Avrich (ed.), God and the State - With a New Introduction and Index of Persons (Dover Publications Inc.: NY).

Barclay, Harold. 20ıо. 'Anarchist Confrontations with Religion.' in Nathan Jun and Shane Wahl (ed.), New Perspectives on Anarchism (Lexington: Lanham).

Beiser, Frederick. 2005. Hegel (Routledge: London). 
Benz, Ernst. I989. The Theology of Electricity (Pickwick Publications: Allison Park).

Beringer, Yasha 2013. 200 Years of Royal Arch Freemasonry in

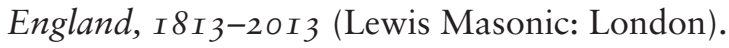

Blanquel, Eduardo. I964. 'El anarco-magonismo', Historia Mexicana, I3: 394-427.

Blavatsky, H. P. . I966. 'An Abridgement of the Secret Doctrine.' in Elizabeth Preston and Christmas Humphreys (ed.) (The Theosophical Publishing House: Illinois).

Bose, Atindranath. 1967. A History of Anarchism (World Press: Calcutta).

Braunthal, Julius. 1967. History of the International, Vol. I- I864I9I4 (Frederick A. Praeger: NY).

Buck-Morss, Susan. 2000. 'Hegel and Haiti', Critical Inquiry, Vol 26: pp. $82 \mathrm{I}-65$.

Buisine, Andrée. I995. 'Annie Besant, socialiste et mystique', Politica Hermetica, 9.

Burke, Peter. 1978. Popular Culture in Early Modern Europe (Cambridge University Press: Cambridge).

Cappelletti, Angel. 1990. 'Prólogo y cronologia - Anarquismo Latinoamericano.' in Carlos and Angel Cappelletti Rama (ed.), El Anarquismo en America Latina (Biblioteca Ayacucho: Caracas).

Cesaire, Aimé 2000 [1955]. Discourse on Colonialism (Monthly Review Press: NY).

Chadwick, Owen. 1975. The Secularization of the European Mind in the Nineteenth Century (the Gifford lectures in the University of Edinburgh for 1973-4) (Cambridge University Press: Cambridge).

Christoyannopoulos, Alexandre and Lara Apps. 2019. 'Anarchism and Religion.' in Carl Levy and Matthew Adams (ed.), The Palgrave Handbook of Anarchism (Palgrave Macmillan: Basingstoke).

Cohn, Norman. I970. The Pursuit of the Millennium: Revolutionary Millenarians and Mystical Anarchists of the Middle Ages (Oxford University Press: Oxford). 
- I966. Warrant for Genocide: The Myth of the Jewish WorldConspiracy and the Protocols of the Elders of Zion (New York: Harper \& Row)

Copenhaver, Brian. I992. Hermetica: The Greek Corpus Hermeticum and the Latin Asclepius in a New English Translation with Notes and Introduction (Cambridge University Press: Cambridge).

- 201 5. The Book of Magic-From Antiquity to Enlightenment (Penguin: NY).

Critchley, Simon 2012. The Faith of the Faithless (Verso: NY).

Cutler, Robert M. 1985. Mikhail Bakunin - From out of the DustbinBakunin's Basic Writings, I 869-7I (Ardis: Michigan).

Darwin, Charles. I964 (I 859 ). On the Origin of Species (A Facsimile of the First Edition) (Harvard University Press: Cambridge).

Doyle, W. 1967. The Parlementaires of Bordeaux at the end of the Eighteenth Century I775-I790 (Oxford D. Phil, thesis: Oxford).

Dubreuil, J. P. I 838. Histoire des Franc-Maçons (H.I.G. François: Bruxelles).

Dufart, P. (libraire) I 8I 2. Histoire de la Fondation $d u$ Grand Orient de France. (L'imprimerie de Nouzou, rue de Clery, No. 9: Paris).

Durkheim, Emile. 2008 [I9I2]. The Elementary Forms of Religious Life (George Allen \& Unwin Ltd: London).

Eckhardt, Wolfgang 20I6. The First Socialist Schism: Bakunin vs. Marx in the International Working Men's Association (PM Press CA).

Edelman, Nicole. I995. 'Somnabulisme, médiumnité et socialisme', Politica Hermetica, 9.

Edwards, L.S. and Elizabeth Fraser. 1969. Selected Writings of PierreJoseph Proudhon (Macmillan and Co. Ltd.: London).

Eisenstein, Elizabeth L. 1959. The First Professional Revolutionist: Filippo Michele Buonarroti (I76I-I837) (Harvard University Press: Cambridge).

Eliade, Mircea. I974 [1949]. The Myth of the Eternal Return - or, Cosmos and History (Princeton University Press: Princeton). 
Engels, Friedrich. I975. 'Progress of Social Reform on the Continent.' in Robert Tucker (ed.), Karl Marx and Friedrich Engels - Collected Works, vol. 3 (International Publishers: NY).

Evans, Kate. 2015. Red Rosa - A Graphic Biography of Rosa Luxemburg (Verso: NY).

Federici, Sylvia 2004. Caliban and the Witch - Women, The Body and Primitive Accumulation (Autonomedia: NY).

Fried, Albert and Ronald Sanders. I964. Socialist Thought - A Documentary History (Anchor Books: NY).

Gabay, Alfred J. 2005. The Covert Enlightenment - Eighteenth Century Counterculture and its Aftermath (Swedenborg Foundation Publishers: West Chester).

Gay, Peter I966. The Enlightenment: An Interpretation (Knopf: New York).

Goodrick-Clarke, Nicolas. I992. The Occult Roots of Nazism: Secret Aryan Cults and Their Influence on Nazi Ideology: The Ariosophists of Austria and Germany, I890-I935 (New York University Press: NY).

Graeber, David. 2002. 'The New Anarchists', New Left Review, I3, January/February: 6I-74.

- 2015. 'Radical alterity is just another way of saying 'reality': A reply to Eduardo Viveiros de Castro', Hau - Journal of Ethnographic Theory, 5 .

Hart, John. I978. Anarchism and the Mexican Working Class, I860I93 I (UT Press: Austin).

Hegel, Georg Wilhelm Friedrich. I977 (I807). Phenomenology of Spirit (Clarendon Press: Oxford).

- 2010 (I8I2). The Science of Logic (Cambridge University Press: Cambridge).

Hill, Christopher. 1975. The World Turned Upside Down - Radical Ideas During the English Revolution (Penguin: Harmondsworth).

Hobsbawm, E. J. 1959. Primitive Rebels - Studies in Archaic Forms of Social Movement in the I9th and 2oth Centuries (Norton: NY). 
Hodges, Donald. I 992. Sandino's Communism - Spiritual Politics for the Twenty-First Century (UT Press: Austin).

Illades, Carlos. 2002. Rhodakanaty y la formación del pensamiento socialista en México (Rubi: Anthropos).

Israel, Jonathan. 200I. Radical Enlightenment (Oxford University Press: Oxford).

2010. A Revolution of Mind-Radical Enlightenment and the Intellectual Origins of Modern Democracy (Princeton University Press: Princeton).

Jacob, Margaret. I98I. The Radical Enlightenment - Pantheists, Freemasons and Republicans (George Allen and Unwin: London).

. I988. 'Freemasonry and the Utopian Impulse.' in R.H. Popkin (ed.), Millenarianism and Messianism in English Literature and Thought (E.J. Brill: NY).

- 2006. Strangers Nowhere in the World - The Rise of Cosmopolitanism in Early Modern Europe (University of Pennsylvania Press: Philadelphia).

James, C.L. . I902. Origin of Anarchism (A. Isaak: Chicago).

Johnson, K. and K. E. Ferguson. 2019. 'Anarchism and Indigeneity.' in M. S. Adams C. Levy (ed.), The Palgrave Handbook of Anarchism (Palgrave Macmillan: Basingstoke).

Konishi, Sho. 20I3. Anarchist Modernity: Cooperatism and JapaneseRussian Intellectual Relations in Modern Japan (Cambridge: Harvard University Press,).

- 2007. 'Reopening the "Opening of Japan": A RussianJapanese Revolutionary Encounter and the Vision of Anarchist Progress', American Historical Review, I I 2: IOI-30.

Kropotkin, Piotr. I955 [I9I4]. Mutual Aid: A Factor of Evolution (Extending Horizons Books: Boston).

Lagalisse, Erica. 20 I 8. Occult Features of Anarchism - With Attention to the Conspiracy of Kings and the Conspiracy of the Peoples (Oakland : PM Press)

- 2016. "Good Politics": Property, Intersectionality, and the Making of the Anarchist Self, PhD dissertation, Department of Anthropology, McGill University, Montreal. 
- 2015. "Anarchism and Conspiracy Theories in North America, or: The Conspiracy Theory as Antidote to Foucault" American Anthropological Association (AAA) Annual Meeting. Denver, CO. December.

-. 20I I. " "Marginalizing Magdalena”: Intersections of Gender and the Secular in Anarchoindigenist Solidarity Activism', Signs Journal of Women in Culture and Society, 36.

- 20I I. 'Participación e influencias anarquistas en el movimiento "Occupy Wall Street” “, Periodico del CNT (Confederación Nacional del Trabajo), $\mathrm{n}^{\circ} 383$, noviembre.

Lakoff, Aaron. 2013. Anarchism and Hope (Howl! arts collective [zine]: Montréal).

Lambert, Malcolm. I992 (I977). Medieval Heresy (Basil Blackwell: Oxford).

Laqueur, Thomas. 2006. 'Why the Margins Matter: Occultism and the Making of Modernity', Modern Intellectual History, 3: I I I-35.

Lauzeray, Christian. I988. L’Égypte ancienne et la Franc-Maçonnerie (Éditeur Guy Trédaniel Paris).

Le Forestier, René. I974 (I9I4). Les Illuminés de Bavière et la FrancMaçonnerie Allemande (Slatkine Megariotis Reprints (Reprint of the I9I4 Paris edition): Genève).

Lea, Henry Charles. I922. A History of the Inquisition of the Middle Ages (Macmillan: London).

Lehning, Arthur. I970. From Buonarroti to Bakunin - Studies in International Socialism (Brill: Leiden).

- I973. Mikhail Bakunin - Selected Writings (University of Michigan Press: Cape).

Levy, Carl. 20II. "Anarchism and cosmopolitanism." Journal of Political Ideologies I6 (3):265-278.

- 2010. 'Social Histories of Anarchism', Journal for the Study of Radicalism, 4: I-44.

- 2004. 'Anarchism, Internationalism and Nationalism in Europe, I860-I939', Australian Journal of Politics and History, 50: $330-42$. 
Levy, R.S. I995. A Lie and a Libel: The History of the Protocols of the Elders of Zion. (University of Nebraska Press: NB).

Linebaugh, Peter, and Marcus Buford Rediker. 2000. The ManyHeaded Hydra: Sailors, Slaves, Commoners, and the Hidden History of the Revolutionary Atlantic (Beacon Press: Boston).

Lomnitz, Claudio. 20I4. The Return of Comrade Ricardo Flores Magón (Zone Books: New York).

Magee, Glenn Alexander. 200I. Hegel and the Hermetic Tradition (Cornell University Press: Ithica and London).

Manuel, Frank E. and Fritzie P. Manuel. 1979. Utopian Thought in the Western World (Harvard University Press: Cambridge).

Marsden, Victor E. (ed). 2006. The Protocols of the Elders of Zion (Filiquarian Publishing LLC).

Marshall, Peter. 1993. Demanding the Impossible - A History of Anarchism (Fontana Press: London).

—. I990 [ı 876]. Capital Vol. I (Penguin: London).

-. [1932] I978. 'The German Ideology.' in Robert Tucker (ed.), The Marx-Engels Reader (W. W. Norton \& Company: NY).

Mehring, Franz 1936. Karl Marx: The Story of His Life ( Fitzgerald: London).

Mulsow, Martin. 2003. “'Adam Weishaupt as Philosoph”.' in W Müller-Seidel and W. Reidel (ed.), Die Weimarer Klassik und ibre Geheimbünde (Würzburg).

Moya, José. 2004. "The positive side of stereotypes: Jewish anarchists in early twentieth-century Buenos Aires." Jewish History I 8 (I): pp. I9-48.

Nettlau, Max. I979 (1929). La anarquía a través de los tiempos (Editorial Antalbe: Barcelona).

Pernicone, Nunzio. I993. Italian Anarchism, I864-I 892 (Princeton University Press: New Jersey).

Preston, William. I 855. The Universal Masonic Library, Vol. III Preston's Illustrations of Masonry (W.Leonard \& Co., Aferican Masonic Agency: NY). 
Raine, Kathleen. I970. William Blake (World of Art) (Thames and Hudson: London).

Reidel, W. 2003. 'Aufklärung und Macht. Schiller, Abel und die Illuminaten.' in W Müller-Seidel and W. Reidel (ed.), Die Weimarer Klassik und ibre Geheimbünde (Würzburg).

Roberts, J. M. I972. The Mythology of the Secret Societies (Secker and Warburg: London).

Robison, John. I798. Proofs of a conspiracy against all the religions and governments of Europe, carried on in the secret meetings of Freemasons, Illuminati, and reading societies (W. Watson and Son: Dublin).

Rose, R.B. I978. Gracchus Babeuf - The First Revolutionary Communist (Stanford University Press: Stanford).

Rosenthal, Bernice Glatzer. I997. 'Introduction.' in Bernice Glatzer Rosenthal (ed.), The Occult in Russian and Soviet Culture (Cornell University Press: Ithica and London).

- I997. 'Political Implications of the Early Twentieth-Century Occult Revival.' in Bernice Glatzer Rosenthal (ed.), The Occult in Russian and Soviet Culture (Cornell University Press: Ithica and London).

Rublack, Ulinka. 20I5. The Astronomer and the Witch - Johane Kepler's Fight for his Mother (Oxford University Press: Oxford).

Sahlins, Marshall. I996. 'The Sadness of Sweetness: The Native Anthropology of Western Cosmology', Current Anthropology, 37: $395-428$.

Said, Edward. I978. Orientalism (Vintage: NY).

Saña, Heleno. I970. El anarquismo, de Proudhon a Cohn-Bendit (Indice: [Madrid]).

Schmitt, Carl. I985 [1922]. Political Theology: Four Chapters on the Concept of Sovereignty (Chicago University Press: Chicago).

Scott, Joan. 2009. "Sexularism." In RSCAS Distinguished Lectures. Florence, Italy.

Simpson, Audra. 20I4. Mohawk Interruptus - Political Life Across the Borders of Settler States (Duke University Press: Durham and London). 
Skeggs, Beverley. 2004. Class, Self, Culture (Routledge: London).

Smith, Andrea. 2005. Conquest - Sexual Violence and American Indian Genocide (South End Press: Cambridge).

- 2008. North Americans and the Christian Right: The Gendered Politics of Unlikely Alliances (Duke University Press: Durham and London).

Spencer, Herbert I 864. Principles of Biology (William and Norgate: London).

Spinoza, Benedictus de. 1963. The Cartesian principles and Thoughts on metaphysics (Bobbs-Merrill: Indianapoli).

- 2000. Ethics. (Oxford University Press: NY).

- 2007 Theological-Political Treatise (Cambridge University Press: NY).

Szajkowski, Zosa. I947. "The Jewish Saint-Simonians and Socialist Antisemites in France.” Jewish Social Studies 9 (I):33-60.

Tambiah, Stanley. I990. Magic, Science, Religion and the Scope of Rationality (Cambridge University Press: Cambridge).

Thomas, Keith. 1982. Religion and the Decline of Magic: Studies in Popular Beliefs in Sixteenth and Seventeenth Century England (Penguin: New York).

Thompson, E.P. 1963. The Making of the English Working Class (Vintage: NY).

Todd, Zoe. 20I 6. 'An Indigenous Feminist's Take On The Ontological Turn: 'Ontology' Is Just Another Word For Colonialism', Journal of Historical Sociology, 29.

Tolstoy, L. 200I. 'The Kingdom of God is Within You: Christianity Not as a Mystical Doctrine but as a New Understanding of Life.' in, The Kingdom of God and Peace Essays (Rupa: New Delhi).

Torres Parés, Javier 1990. La Revolución sin Frontera: el Partido Liberal Mexicano y las relaciones entre el movimiento obrero de México y de los Estados Unidos, I900-I923 (Ediciones Hispánicas).

Trejo, Ruben. 2005. Magonismo: utopia y revolucion, I9IO - I9I3 (Cultura Libre: Mexico, D.F.). 
Tsing, Anna 20I 5. The Mushroom at the End of the World - On the Possibility of Life in Capitalist Ruins (Princeton University Press: NJ).

Unknown. 1744. La Franc-Maçonne ou révélation des mystères des franc-maçons (Brussels).

Valín Fernández, Alberto. 2008. Masonería y revolución - Del mito literario a la realidad historica (Santa Cruz de Tenerife: Ediciones Idea).

. 2005. 'De masones y revolucionarios: una reflexión en torno e este encuentro', Anuario Brigantino, 28: 173-98.

van der Veer, Peter. 200I. Imperial Encounters - Religion and Modernity in India and Britain (Princeton University Press: Princeton).

Van Dülman, Richard. 1975. Der Geheimbund der Illuminaten (Stuttgart).

Veysey. 1973. The Communal Experience - Anarchist and Mystical Counter-Cultures in America (Harper and Row: New York and London).

Vondung, Klaus. I992. 'Millenarianism, Hermeticism, and the Search for a Universal Science.' in Stephen McKnight (ed.), Science, Pseudoscience, and Utopianism in Early Modern Thought (University of Missouri Press: Columbia).

Webb, James. 1976. The Occult Establishment (Open Court Publishing Company: Illinois).

Webster, Nesta Helen. I936. Secret Societies and Subversive Movements (Boswell: London).

Westcott, Dr. William Wynn I9r2. A Catalogue Raisonné of works on the Occult Sciences, Vol III - Freemasonry, A Catalogue of Lodge Histories (England), with a Preface (F.L. Gardner: London).

Westfall, Richard S. I972. 'Newton and the Hermetic Tradition.' in Allen G. Debus (ed.), Science, Medicine and Society in the Renaissance (Science History Publications: New York).

Woodcock, George. I962. Anarchism - A History of Libertarian Ideas and Movements (The World Publishing Company: Cleveland). 
332 Essays in Anarchism and Religion: Volume II

Yates, Frances. 1964. Giordano Bruno and the Hermetic Tradition (University of Chicago Press: Chicago).

- 1966. The Art of Memory (Routledge: London).

- 2002 [1972]. The Rosicrucian Enlightenment (Routledge: London). 